\title{
Geographic Diversification and Agency Costs of Debt of Multinational Firms
}

\author{
John A. Doukas and Christos Pantzalis
}

October 3, 2001

\begin{abstract}
This paper examines the agency conflicts between shareholders and bondholders of multinational and nonmultinational firms and provides an explanation for the puzzle that multinational firms use less long-term debt but more short-term debt than domestic firms. Using a sample of 6,951 firm-year observations for multinational and domestic firms over the 1988-1994 period, we find that alternative measures of agency costs have statistically significant negative effects on firm long-term leverage. The results, however, also show that the negative effects of agency costs of debt on long-term leverage are significantly greater for multinational than non-multinational firms. It is documented that the effect of the agency costs of debt on leverage are increased by the firm's degree of foreign involvement. The evidence shows that firm's increasing foreign involvement exacerbates agency costs of debt leading to lower (greater) use of long-term (short-term) debt financing. This result is also confirmed using alternative measures of foreign involvement. The evidence is consistent with the view that multinational corporations are susceptible to higher agency costs of debt than domestic corporations because geographic diversity renders active monitoring more difficult and expensive in comparison to domestic firms. The results fail to support the view that MNCs' lower long-term debt ratios are due to the advantages of the internal capital markets.
\end{abstract}

*Department of Finance, Stern School of Business, New York University, New York, NY 10012, School of Business and Public Administration, Old Dominion University, Norfolk, VA 23529-0218, Tel: (757) 683-5521, Fax: (757) 683-5639, E-mail: jdoukas@odu.edu, Distinguished Senior Research Fellow, Cardiff Business School, Cardiff, UK and Department of Finance, College of Business Administration, University of South Florida, Tampa, FL 33620-5500, Tel: (813) 974-6326, Fax: (813) 974-3030, E-mail: cpantzal@coba.usf.edu, respectively. We would like to thank an anonymous referee and participants at the 1997 FMA meetings for useful comments and suggestions that have improved the paper. 


\section{Geographic Diversification and Agency Costs of Debt of Multinational Firms}

\section{Introduction}

Although the positive and negative attributes of debt as a corporate financing instrument have been theoretically and empirically examined, the impact of agency costs of debt on the financial structure of multinational corporations (MNCs) remains unknown. ${ }^{1}$ Furthermore, the documented puzzle that multinational firms have less long-term debt but more short-term debt than domestic firms also warrants investigation.

Recent empirical evidence indicates that firms with foreign operations have greater growth opportunities than firms with only domestic operations (Bodnar and Weintrop (1997) among others). Doukas (1995) shows that expansion of foreign operations by US multinational firms, does not elicit a positive market reaction due to market's perception of increasing agency costs in managing geographically diverse operations. Consistent with Myers (1977), these results imply that MNCs may be subject to greater agency costs of debt than domestic firms. ${ }^{2}$

While recent studies show that debt ratios are inversely related to the firm's agency costs of debt, estimates of the agency cost implications on debt for geographically diversified firms do not exist. ${ }^{3}$ The issue of geographic diversification on firm leverage has been ignored despite the fact that

1 The theoretical literature includes the work of Modigliani and Miller (1958), Myers (1977), Jensen (1986), and Stulz (1990), among others, while the empirical literature contains studies by Holderness and Sheehan (1988), Morck, Shleifer and Vishny (1988), McConnell and Servaes (1990,1995), Hermalin and Weisbach (1991), Phelps, Moore and Roenfeld (1991), Kole (1994), and Lang, Ofek and Stulz (1996), among others.

2 Myers(1977) shows that firms with higher-valued investment opportunities have higher agency costs of debt.

3 See, for example, Titman and Wessels (1988) and Long and Malitz (1985). Prowse(1990) has examined the effects of agency costs on leverage for US and Japanese firms. The evidence of these studies suggests that debt ratios are inversely related to the firm's potential to engage in risky and sub-optimal investments. These findings are consistent with the notion that agency problems increase when sub-optimal 
many US corporations maintain operations in several countries. The geographic structure of these corporations may exacerbate or mitigate the inherent conflict between shareholders and debtholders. This lack of control for geographic diversification permits a bias in existing estimates of the negative relation between leverage and agency costs of debt due to a correlated omitted variable problem. Since a considerable number of firms, considered in previous studies, are industrially and geographically diversified, this potential bias needs to be accounted for in order to obtain a more precise estimate of the impact of agency costs of debt on firm leverage. Because MNCs are typically also industrially diversified, they offer a unique opportunity to examine the effects of agency costs of debt on leverage in a framework where we simultaneously control for both dimensions of diversification.

In this paper we estimate the relation between leverage and alternative measures of agency costs of debt for U.S. multinational and non-multinational corporations. Our approach allows us to estimate the independent effects of geographic and industrial diversification on firm leverage. Specifically, we use industry segment and geographic diversification data to address the question of whether MNCs are plagued by more severe agency cost of debt problems than domestic firms. While past studies have shown that MNCs tend to make less use of long-term debt than domestic firms (Fatemi (1988) and Lee and Kwok (1988)), they fail to explain why multinational firms have less long-term debt but more short-term debt than domestic firms. Our interest on the capital structure of MNCs and non-MNCs is also motivated by the need to examine why multinational firms may exhibit distinctly different financial structures than firms without international involvement. ${ }^{4}$

investment decisions are made that compromise debtholder interests.

${ }^{4}$ As Burgman (1996) states "most of the empirical literature on capital structure has either completely ignored international factors, or implicitly assumed that they are adequately proxied by the standard business risk measures". While Fatemi (1988) and Lee and Kwok (1988) compare leverage measures of MNC and domestic firms they do not examine the relation between leverage and capital structure determinants for the two types of firms. 
There are several reasons one would expect MNCs to have different leverage ratios than domestic firms. First, MNCs have access to more sources of capital than domestic firms as a result of the international nature of their operations. Therefore, to the extent that financial markets are not integrated MNCs could raise more capital through foreign debt financing and at more favorable terms than domestic firms. ${ }^{5}$ For example, consider the case of MNCs with subsidiaries in countries with different tax rates on interest payments. MNCs can benefit by borrowing through foreign affiliates exposed to high tax rates, thus increasing their interest tax shields (see Butler (1999), p.416). Hence, access to external sources of financing should result in higher debt ratios for MNCs than domestic firms. Thomadakis and Usmen (1991) show that, under segmented capital market conditions, foreign risky debt can increase shareholder wealth. However, easier access to foreign financial markets by MNCs may also result in equity rather than debt financing. Consequently, the expected relation between the international operations of the firm and debt financing is non-negative. Second reason for expecting MNCs to display higher debt ratios than domestic firms is the that foreign debt can be used as a hedging instrument against foreign exchange risk. ${ }^{6}$ Because MNCs have higher levels of foreign exchange exposure than domestic firms, it is expected that they make greater use of debt financing than domestic firms. Furthermore, a large proportion of foreign currency denominated debt can be motivated by the need of MNCs to partially hedge against country and political risk exposures. Consequently, because MNCs are subject to currency, country and political risk exposures they are expected to have higher overall debt ratios than domestic firms. Apparently, the capital structure of MNCs is more likely to have a larger component of foreigndenominated debt than non-MNCs. Thus, the expected relation between foreign involvement and

\footnotetext{
${ }^{5}$ Market segmentation is caused by market imperfections, such as informational barriers, differing tax and legal systems, government regulations and restrictions imposed on capital flows, etc.

${ }^{6}$ Kedia and Mozumdar (1999) show that firms with high aggregate foreign exchange exposure tend to issue more foreign currency denominated debt.
} 
leverage is non-negative. Third, since the operations of MNCs are industrially and geographically diversified, the business and financial risk of multinational corporations is expected to be lower in comparison to that of domestic firms. This would tend to reduce the cost of debt and as a result raise MNCs' leverage. Therefore, this suggests that financial distress should have a negative and greater bearing on the leverage of domestic firms than MNCs, while MNCs' leverage should be positively related with foreign involvement.

While liquidity, hedging, financial distress and operating considerations imply that MNCs are likely to have greater leverage than firms without foreign involvement, empirical studies show that MNCs have lower long-term leverage than domestic firms (Fatemi (1988) and Lee and Kwok (1988)). There are three possible explanations for this finding. The first is associated with the potential efficiencies of internal capital markets. The second explanation relates to the potential effects of agency costs of debt. Another reason that MNCs have lower long -term leverage could be attributed to the legal and institutional differences that persist across counties (Demirguc-Kunt and Maksimovic (1999), Booth, Aivazian, Demirguc-Kunt and Maskimovic (2001)) where MNCs have operations.

The effects of internal capital markets and agency costs of debt on firm leverage have not received the required attention in the finance literature. Unlike previous studies, our empirical tests are designed to address the agency costs of debt of MNCs in comparison to domestic firms, while we control for the effects of internal capital markets on leverage. We argue that because MNCs are geographically more diversified than domestic corporations they are more likely to be associated with higher agency costs of debt problems than domestic firms. We hypothesize that if geographically diversified firms suffer from higher agency costs of debt than domestic firms, the relation between leverage and different measures of debt agency costs should be negative and more pronounced for MNCs. 
Our results show that the capital structure of multinational corporations differs significantly from that of domestic firms, in that MNCs tend to display lower long-term debt ratios and higher short-term debt ratios than domestic firms. We also find the long-term debt ratios of multinational corporations to be negatively related to the firm's potential to engage in risky, suboptimal investments, whereas the long-term debt ratios of non-MNCs are shown to be substantially less negatively influenced by agency costs of debt in comparison to MNCs. This implies that MNCs have significantly higher agency costs of debt than domestic firms. Furthermore, we find that the agency costs of debt are positively related to the firm's degree of international involvement. In particular, our findings show that MNCs make less (more) use of long-term(short-term) debt financing because they are subject to higher agency cost of debt than domestic firms. This result remains robust even after controlling for the degree of industrial diversification, the structure of foreign operations and the ownership structure characteristics of the firm. Our evidence is consistent with the view that multinational corporations are subject to higher agency costs than domestic corporations because international diversity increases information asymmetries rendering active monitoring more difficult and expensive for MNCs in comparison to domestic firms. ${ }^{7}$

The remainder of the paper is organized as follows. In the next section we discuss the effects of internal capital markets and agency costs of debt on firm leverage. In Section 3 we provide a description of the data sources and the sample selection procedure, as well as the empirical methodology. Section 4 contains the empirical results. Concluding remarks are provided in Section 5.

\section{The Effects of Internal Capital Markets and Agency Costs of Debt on Firm Leverage}

\subsection{Internal capital markets and firm leverage}

\footnotetext{
${ }^{7}$ In the context of corporate diversification, Doukas and et al.(2000) show that the monitoring effectiveness of security analysts decreases with diversification.
} 
Because MNCs consist of numerous divisions operating across industries and countries, it can be argued that their operations allow them to create extensive internal capital markets that are likely to provide them with cheaper financing than the external markets. Hence, if internal capital markets work efficiently, MNCs are expected to rely more on internal than external financing and, therefore, have lower leverage than domestic firms that lack MNCs' depth of internal capital markets. Consequently, a non-positive relation is predicted between the firm's foreign operations and leverage when internal capital markets bypass the informational asymmetries of external capital markets (Stein (1997)). Recently, Scharfstein and Stein (1997) and Matsusaka and Nanda (1997) consider the improved allocation of capital in internal capital markets and the associated agency costs for diversified firms. ${ }^{8}$ They show that diversified firms can utilize internal capital markets to fund profitable projects that, because of agency costs and information asymmetries, cannot be financed in external capital markets. This implies that MNCs' external debt financing needs will be attenuated and, therefore, MNCs' lower leverage should reflect the strengths of internal capital markets. This view predicts a negative relation between industrial diversification and MNCs' leverage. Therefore, the debt ratios of MNCs (i.e., firms with internal capital market advantages) should exhibit an inverse and more pronounced association with industrial diversification (i.e., number of business segments ) than non-MNCs. ${ }^{9}$

Several authors (Williamson (1975, 1986), Myers and Majluf (1984), Shleifer and Vishny (1992), Stein (1997), and Lewellen (1971)), however, argue that diversified corporations create internal capital markets, which are less prone to asymmetric information problems and hence they can sustain higher levels of debt. This implies a positive relation between industrial diversification

\footnotetext{
${ }^{8}$ See Lamont (1997), Lang, Ofek and Stulz(1994), Houston, James and Markus (1996), and Scharfstein (1997) for evidence on the functioning of internal capital markets.

${ }^{9}$ Most of the empirical evidence, however, indicates that internal capital markets do not work (Lamont (1997), Rajan, Servaes and Zingales(2000), Shin and Stulz (1998), and Lins and Servaes (1999a,1999b)).
} 
and firm leverage. In addition, it is expected that this relation should be stronger for MNCs than domestic firms since MNCs are likely to be more industrially diversified than domestic firms. The

two opposite views of the effects of the internal capital markets on firm leverage are tested by examining the relation between corporate diversification and firm leverage. Furthermore, we test for the effects of increased internal capital market advantages on leverage that may arise from the geographic diversification of MNCs. The two competing views associated with the effects of the internal capital market advantages on firm leverage should be amplified if geographic diversification increases the internal capital market advantages of the firm.

\subsection{Agency costs of debt and firm leverage}

The negative effects of agency costs of debt on MNCs' leverage arise from their geographic diversity. Because the operations of MNCs are geographically dispersed, difficulties in gathering and processing information make monitoring more costly than the cost of monitoring domestic firms. Hence, it is expected that the inherent agency problem between shareholders and debtholders will be exacerbated with the diverse geographic structure of MNCs and, therefore, bondholders will require higher interest payments on loans to firms that are more susceptible to information asymmetries and greater monitoring costs. This implies that diversified firms across countries are likely to have lower debt ratios than pure domestic firms. Furthermore, it is expected that the negative relation between leverage and agency costs of debt will be more pronounced for firms with greater foreign involvement. Thus, the agency costs of debt view on firm leverage predicts that MNCs' leverage should be inversely related with agency costs of debt and that this relation should be more pronounced in comparison to domestic firms.

The internal capital market view on firm leverage, however, predicts that MNCs' leverage should be positively related with internal capital markets and it should be considerably more 
pronounced in comparison to domestic firms. A competing prediction of the internal capital markets view, suggests that MNCs' leverage should be negatively related with internal capital markets. Testing for the effects of the agency costs of debt on leverage requires to control for the possible effects of internal capital markets. If a positive relation between the MNCs' leverage and internal capital markets is found, while simultaneously an inverse relation is documented between MNCs' leverage and agency costs of debt, then, that would suggest that the agency costs of debt have a distinct influence on firm leverage. Furthermore, if the agency costs of debt exert a negative and more amplified influence on the leverage of MNCs than non-MNCs it would imply that the agency costs of debt are exacerbated by the firm's foreign involvement. Since MNCs' leverage could be influenced by the legal and institutional characteristics of the host country, our analysis is designed to control for such effects as well. Therefore, agency costs of debt aspects of multinational firms warrant a closer examination.

\section{Data and Methodology}

\subsection{Data selection and sources}

The sample consists of mining, agricultural and manufacturing firms over the 1988-1994 period. The sample includes U.S. MNCs and pure domestic (non-MNCs) corporations. Originally, we considered all firms with four-digit SIC industry codes of 3999 or less in the Compustat PC Plus database. Excluding firms with missing financial and ownership structure information resulted in a final sample of 6,951 firm-year observations. In this study a firm is defined as an MNC if it reports foreign assets and foreign sales ratios of $10 \%$ or more. This classification is based on the requirements of the Statement of Financial Accounting Standard No. 14 (FASB 1976), where MNCs are identified as firms that report ratios of foreign assets, foreign sales or foreign income of at least 
$10 \% .{ }^{10}$ Firms are classified as domestic if they do not report any foreign assets and foreign sales. ${ }^{11}$ The financial data and the number of business segments for the period 1988-1994 were extracted from the Compustat PC Plus CD-Rom database.

The common equity ownership data over the same period were obtained from the Compact Disclosure CD-Rom database. Disclosure ownership data are compiled from the different SEC filings included in the Spectrum databases. The data represent end of the year percentage of common shares owned by insiders (members of the board of directors), blockholders ( investors owning at least $5 \%$ of the outstanding shares), and institutional investors. ${ }^{12}$

The intersection of the above data sets resulted into 2,502 and 4,449 firm-year observations for U.S. MNCs and domestic firms, respectively, for which leverage ratios could be computed over the 1988-1994 period. Because of missing market-to-book observations, the tests that include a variable based on market-to-book display a lower number of observations (2266 and 3855 observations for MNCs and domestic firms, respectively).

Table 1-Panel A provides a comparison of the means of the three leverage ratios (total debt ratio ( $L E V$ ), long-term debt ratio $(L T D)$, and short-term debt ratio $(S T D)$ ), between the MNC and domestic samples, across different industries. Firms are assigned to different industries based on their primary two-digit SIC industry code. $L T D$ is measured as the ratio of Long Term Debt to Total Debt plus Market Value of Equity. STD is measured as the ratio of Debt in Current Liabilities to Total Debt plus Market Value of Equity. The STD measure is constructed so that it does not include

\footnotetext{
${ }^{10}$ We choose the foreign assets and foreign sales ratio over the foreign income criterion, because foreign income is not reported uniformly across firms.

${ }^{11}$ A less stringent classification of domestic firms that allows all firms that have foreign asset or foreign sales ratios of less than $10 \%$ to be labeled as domestic was also investigated. The results are qualitatively similar to the ones presented here and are available from the authors upon request.

12 According to the ownership definitions of Disclosure, institutional holders may include blockholders and the blockholders may include both institutions and insiders.
} 
accounts payable and accrued expenses which may fluctuate seasonably and may not represent ongoing sources of short term financing. $L E V$ is the sum of STD and $L T D$. Debt ratios vary considerably across industries and across type of firms. In thirteen out of the twenty two industries LTD is lower for the MNC group in comparison to the non-MNC group. STD is higher for MNCs in twelve industries. Table 1 - Panel A implies that a thorough examination of the determinants of firm's leverage should control for industry effects. The pooled sample averages reveal that while the total debt ratios are very similar, MNCs display higher short-term debt ratios and lower long- term debt ratios than domestic firms. A closer comparison of aggregate debt ratios between domestic firms and MNCs with different degrees of foreign involvement is reported in Table 1 - Panel B.

\section{[ Insert Table 1 Panel A About Here ]}

Panel B provides the means and medians of the leverage variables as well as the t-statistics and the Wilcoxon rank sum z-scores for the means and medians difference tests between the domestic sample (DOM) and several MNC samples consisting of firms classified based on their degree of foreign involvement measured by the levels of their foreign assets (FAR) and foreign sales ratios (FSALER). The means difference tests show that $L T D$ (STD) is significantly lower (higher) for MNCs than for domestic firms. The Wilcoxon rank sum z-scores indicate that STD is significantly higher for MNCs than domestic firms while this is not the case for $L T D$ with the exception of the first group of MNCs. Finally, the means and medians difference tests do not provide significant results for the total debt ratios (LEV). Overall, the results from Panel B of Table 1 indicate that MNCs have, on average, lower $L T D$ and higher STD, but their overall debt ratios are not much different than that of domestic firms. ${ }^{13}$ The evidence here is generally consistent with previous research that indicates that larger firms (such as MNCs) have lower long-term debt ratios and higher short-term debt ratios. Chung (1993) in an empirical study rejects the hypothesis that larger

\footnotetext{
${ }^{13}$ We compared the average of quarterly STD ratios to calendar year-end STD ratios by 2-digit SIC code industry and found no significant differences, indicating that STD is not driven by cash-flow seasonality.
} 
firms have larger long-term debt capacity, and argues that larger firms have easier access to shortterm borrowing than smaller firms. Since MNCs are likely to be assigned higher credit ratings than domestic firms, our evidence seems to be also consistent with Diamond (1991), who argues that borrowers with higher credit ratings prefer short-term debt, while those with somewhat lower ratings prefer long-term debt. In addition, if MNCs are subject to severe informational asymmetries and more pronounced agency cost of debt problems, our findings are consistent with Barclay and Smith (1995) and Easterwood and Kadapakkam (1994) who show that firms with higher information asymmetries tend to issue more short-term debt. Furthermore, Panel B of Table 1 provides a comparison of convertible debt ratios (measured as a fraction of long term debt) between domestic and the different MNC corporations. Apparently, the proportion of convertible debt used by MNCs in comparison to domestic corporations is significantly larger, indicating that MNCs' greater use of convertible debt is directed towards mitigating agency problems of debt." This also implies that they are likely to be subject to more pronounced agency costs than domestic corporations.

\section{[ Insert Table 1 Panel B About Here ]}

Panel $\mathrm{C}$ of Table 1 provides the means and standard deviations of the variables measuring the firms' potential for agency cost of debt, and of the other control variables included in our regression analysis for the $\mathrm{MNC}$ and domestic sample, as well as the t-statistics for the means difference test between the two samples. The t-statistic is significant for the short-term debt and long-term debt ratios, verifying the evidence reported in Panel A that MNCs use more short-term and less long-term borrowing. The domestic group has higher mean values of the proportion of the firm's assets not tied up in fixed plant and equipment $\left(A D_{2}\right)$, and of a proportional measure of free cash flow $\left(A D_{3}\right)$, in comparison to the MNC group. Interestingly, since these variables proxy for the

\footnotetext{
${ }^{14}$ Bodie and Tauart (1978) araue that includina a call obtion in lona-term debt can mitiaste underinvestment and other aaenev droblems. Thus. both convertible and tallable debt can be used to reduce ageney costs of debt and provide an alternative to avoiding long-term debt in the presence of agency costs.
} 
potential of agency costs, one would expect to find the opposite. It should be noted however that whether the differences in leverage between MNCs and domestic firms are due to agency costs of debt or due to the existence of more efficient internal capital markets for MNCs, cannot be detected from univariate tests alone.

MNCs, on average, report a higher number of business segments than domestic firms. The difference between the two samples is statistically significant at the $1 \%$ level (with a t-statistic of 9.64). This implies that MNCs are considerably more diversified than domestic firms. ${ }^{15}$ MNCs are also different from domestic firms in terms of equity ownership structure. MNCs have considerably lower mean insider shareholdings (INSIDE) and higher mean institutional shareholdings (INSTIT) than domestic firms. This implies that firms without international involvement are characterized by higher insider ownership concentration than MNCs. There are no significant differences in terms of the mean outside blockholdings (OUTBLOCK) between MNCs and domestic firms. The sample also suggests that domestic firms have higher operating risk (OPRISK), and lower past profitability (PROF) and levels of non-debt tax shields (NDTS) than MNCs. ${ }^{16}$ The mean value of the current assets as a percentage of total assets $(C A / T A)$ is significantly lower for MNCs. This implies that the greater use of short-term debt by MNCs is not part of a "matching" strategy, that would require firms

\footnotetext{
${ }^{15}$ We also experimented with two alternative corporate focus measures. FOCUS: Corporate focus, measured as RDIV / (RDIV+UDIV), where RDIV (related diversification) is the number of 4-digit SIC codes within the firm's primary 2-digit SIC code industry, and UDIV (unrelated diversification) is the number of 2-digit (SIC) codes outside the firm's primary 2-digit SIC code industry. CON: concentration within the firm's primary 2-digit SIC code industry, measured as RDIV / SIC4, where SIC4indicates the total number of 4-digit SIC reported codes . Based on the corporate focus measure (FOCUS), our sample shows that non-MNCs are significantly more focused ( less diversified) than MNCs. Using an alternative corporate focus measure (CON), the sample of firms indicates that the business operations of domestic firms are significantly more concentrated ( focused) within their primary two-digit SIC code industry than MNCs. This SIC count-based measure differs conceptually from the Herfindahl-based measures of corporate diversification used in other studies (see among others Lang and Stulz (1994), and Comment and Jarrell (1995)). It is closer related to the number-of-segments measure (e.g., Lang and Stulz (1994)) that essentially captures the same effects as the Herfindahl measure.

${ }^{16}$ This is not consistent with Fatemi's (1988) evidence which shows, among other factors contributing to MNCs' lower debt ratios, that MNCs have higher expected non-debt tax shields.
} 
with higher short-term debt ratios to carry more current assets in order to obtain desired current ratios.

[Insert Table 1 Panel C About here ]

Overall, the sample characteristics recorded in Table 1 suggest that MNCs have higher (lower) short-term debt (long-term debt) ratios than domestic firms. Average total leverage ratios (LEV) are not significantly different between MNCs and domestic firms in the sample. These ratios, however, vary considerably across industries. As expected, MNCs also appear to be more industrially diversified and more widely held than non-MNCs, implying that diversification and/or equity ownership structure could explain potential capital structure differences between MNCs and domestic firms. Consequently, examination of the agency cost of debt hypothesis requires that we control for corporate diversification and ownership structure effects.

\subsection{Methodology}

To examine whether the international operating structure of the firm exacerbates the agency costs of issuing debt in comparison to firms without international involvement we conduct a comparison of the effects of agency cost of debt on long-term leverage using a sample of 2,502 and 4,449 year-firm observations for U.S. MNCs and non-MNCs, respectively, over the 1988-1994 period. Specifically, we analyze the extent to which the shareholder-bondholder agency problem is significantly higher for MNCs than non-MNCs. If the international character of MNCs raises the agency costs of issuing debt, MNCs should have lower debt ratios than non-MNCs with lower such costs. That is, if the diversified operating structure of MNCs results into higher agency costs rational investors are expected to demand a higher discount for holding debt issued by MNCs in relation to domestic firms with lower agency costs. Therefore, agency cost measures should exhibit a significant negative relation with MNCs' leverage, whereas for non-MNCs the relation should be negative and less pronounced. It has been shown (Barclay and Smith(1995) and Easterwood and 
Kadapakkam (1994)), however, that firms with higher informational asymmetries issue more shortterm debt. Moreover, Diamond (1991) argues that larger firms have easier access to short-term capital than smaller firms. Therefore, the notion that higher agency and informational costs have an adverse effect on the debt capacity of MNCs may understate the impact of agency costs on total leverage because firms with high agency costs are likely to resort to short-term debt. Hence, it is appropriate to examine whether agency costs reduce the long-term debt of the firm. Furthermore, because long-term debt is more likely to be used for funding long-term investment projects, agency costs of debt are expected to have a greater impact on the firm's long-term leverage. This hypothesis is tested, controlling for the firm's degree of industrial diversification and other characteristics, using a modified regression model for firm long-term leverage ${ }^{17}$ used in previous studies by Titman and Wessels (1988) and Prowse (1990): ${ }^{18}$

$L T D=f(A D, S E G N U M, O P R I S K, N D T S$, PROF, SIZE, DIVPOR, STDLIB, INSIDE, OUTBLOCK, INSTIT)

The firm's long-term leverage ratio, $L T D$, is measured as (Long-Term Debt)/(Total Debt+Market Value of Equity). We use three agency costs of debt, $A D$, measures that have been used in other empirical studies (e.g., Titman and Wessels(1988) and Prowse(1990) among others). The first agency cost of debt measure, $A D_{1}=$ Market-to-book ratio of equity, measures the firm's future growth opportunities. The growth opportunities of the firm can be viewed as a call option held by the equity holders. As shown in Myers (1977), in the presence of risky debt, these options may be left unexercised because the valuation gains from their exercise would accrue to the firm's bondholders in the form of reduced risk of their claims on the firm. Thus, firms with greater growth

\footnotetext{
17 This model is based on those used by Titman and Wessels (1988), and Prowse (1990), with the addition of the corporate diversification and the ownership structure variables.

18 Prowse (1990) compared the magnitude of the debt agency problem of U.S. firms with a sample of Japanese firms. He provided evidence that the debt agency problem is less severe in Japan than in the U.S., and based this finding on the fact that Japanese financial institutions take large positions in firms to which they lend, thereby mitigating the agency conflict.
} 
opportunities should be more susceptible to agency costs of debt. ${ }^{19}$ The second agency cost of debt measure, $A D_{2}=[($ Total Assets $) /($ Gross Fixed Assets $)]$, measures the firm's non-collateralized assets. The higher the $A D_{2}$ ratio the larger the proportion of non-collateralized assets. Since equity holders find it easier to engage into wealth-transferring actions when the non-collateralized assets of the firm are of large proportions, this is considered an appropriate measure of debt agency costs. That is, shareholders are less likely to be motivated by wealth transfer incentives at the expense of bondholders when more of the firm's total assets are fixed (i.e., fixed plant and equipment). The third agency cost of debt measure, $A D_{3}=$ (Operating Income before Depreciation-Interest ExpensesTaxes-Dividends)/(Total Assets), represents the liquidity of the firm's assets. Dividends refer to the sum of common and preferred stock. In other words, this measure reflects the available free cash flows that can be manipulated by the shareholders at the expense of debtholders.

To account for the industrial diversification of the firm, we introduce the SEGNUM variable. The SEGNUM variable represents the firm's reported number of business segments. ${ }^{20}$ Since, the number of business segments proxies for the extent of the firm's internal capital markets, the sign and magnitude of the coefficient of the SEGNUM variable will provide evidence on the impact of internal capital markets on firm's leverage. If internal capital market efficiencies increase the debt capacity of the firm (Williamson $(1975,1986)$, Myers and Majluf (1984), Shleifer and Vishny (1992), Stein (1997), and Lewellen (1971)), the coefficient of the SEGNUM variable should be positive and significant. However, if internal capital markets bypass information asymmetry problems associated

${ }^{19}$ Alternatively, we have used the R\&D intensity of the firm as a measure of potential for debt agency costs. The results are consistent with the evidence presented here even though the sample size was considerably smaller due to missing observations of R\&D expenditures for many firms. R\&D intensity is often used as a measure of debt agency costs because R\&D investments are considered long-term and risky projects that are difficult to be monitored by debtholders. Therefore, creditors find it practically impossible to engage into contracting with equity holders in order to prevent from being exploited by them. Hence, the R\&D intensity measure captures the firm's range of options for discretionary behavior.

20 This measure has also been used in the corporate diversification literature (see, for example, Lang and Stulz(1994) and John and Ofek (1995) 
with external capital markets, external financing will be less attractive to firms with internal capital market advantages and the coefficient of the SEGNUM variable should be negative.

The operating risk variable, OPRISK, measured by the standard deviation of earnings before interest and taxes (EBIT) divided by sales over the past five years, represents the expected costs of bankruptcy. It is expected that firms with higher operating risk will have less capacity to sustain high debt ratios. However, because MNCs have more diversified operations and stable cash flows than non-MNCs, financial distress should have more pronounced effects on the leverage of domestic firms than MNCs. Because firms can employ several non-debt tax shields to reduce taxes, we introduce a non-debt tax shield variable, NDTS=[Operating Income-Interest Expense(Total Taxes paid/corporate tax rate)]/Sales, to control for the effects of different tax shields that tend to reduce the firm's tax burden. A similar non-debt tax shield measure has also been used by Titman and Wessels (1988) and Prowse (1990). The average corporate tax rate is assumed to be $43 \%$ (i.e., $38 \%$ post-1986 federal tax rate, and 5\% state tax rate (see Gomi (1986)). The ability of the firm to use retained earnings over external finance is measured by its past profitability, $P R O F=$ Average (Net Income/Sales), for the past three years. The past profitability measure, is motivated by the firm's pecking order preferences for raising capital (Myers and Majluf (1984)).

Since several studies have suggested that leverage is a function of firm size ${ }^{21}$ we include the size variable (SIZE=The book value of the firm's total assets) in the model to account for possible size effects on leverage. If larger firms have a greater internal capital markets advantage than smaller firms, it is expected that they will have more resources available to undertake new investment projects and, therefore, size should be inversely related with leverage. On the other hand, size may have a positive effect on leverage because it reduces bankruptcy risk. It should be noted that all these variables are computed as of the end of each calendar year for the period 1988-

\footnotetext{
21 See for example, Warner (1977), Ang, Chua and McConnell (1982), Smith (1977), and Titman and Wessels (1988) among others.
} 
1994. We also include the dividend payout ratio $(D I V P O R)$ to control for dividend policy. This is done because high payout firms may have no internal capital available regardless of its internal capital market efficiency. In addition, high dividend payouts may indicate the ability of the firm to generate profits in the future that may enable firms to borrow more. Finally, we also include a variable, STDLIB, that captures the volatility of interest rates. STDLIB is measured by the standard deviation of the 3-month Euro-dollar deposit rates. We used weekly bank bid interest rates in London (LIBID). Since volatile interest rates would reduce the appeal of external borrowing, a negative relationship is expected between $S T D L I B$ and leverage.

Another factor that may impact on the capital structure decisions of the firm is its ownership structure..$^{22}$ The choice of financing policies as means of reducing conflicts of interest between managers and shareholders has been examined in several studies ${ }^{23}$. Novaes and Zingales (1995) show though, that the choice of debt that would be optimal for shareholders is generally different from the choice made by entrenched managers. Berger, Ofek and Yermack (1997) provide evidence that managers who become entrenched may deviate from choosing the optimal leverage due to agency costs of managerial discretion ${ }^{24}$. Hence, these studies imply that ownership structure variables should be an integral part of a model examining the effects of debt agency costs on leverage.

The last three variables in model (1) are used to account for the ownership structure effects on leverage. The INSIDE variable represents the percent of common shares outstanding owned

\footnotetext{
22 Denis, Denis and Sarin (1997) provide empirical evidence that value reducing diversification was the outgrowth of agency conflicts between managers and shareholders and that the increased monitoring from the market for corporate control led to the reversal of the diversification trend in favor of increased corporate focus in the 1980 s.

${ }^{23}$ See among others Stulz(1988), Kim and Sorensen (1986), Smith and Watts (1992), Lang, Ofek and Stulz(1996), Agrawal and Knoeber (1996).

${ }^{24}$ In a cross sectional study Berger, Ofek and Yermack (1997) find that the leverage levels are lower when CEOs are entrenched, i.e. when CEOs do not face intense monitoring from outside shareholders, when their compensation is not tied to performance, or when they already own a large proportion of the outstanding shares.
} 
by insiders (i.e., corporate officers and members of the firm's board of directors). The OUTBLOCK variable measures the percent of common shares owned by outside blockholders (i.e., stakeholders of $5 \%$ or more of the total outstanding shares that are not insiders). The OUTBLOCK measure may include individual or institutional investor block shareholdings. The OUTBLOCK is a measure of ownership concentration and monitoring intensity, since shareholders with substantial stakes in a firm have an incentive to monitor managerial decisions. In addition, the existence of outside blockholders should reduce free rider problems that arise when small outside shareholders attempt to monitor insiders. The last ownership variable, INSTIT, measures the percent of common shares owned by institutional investors. Institutional ownership indicates the degree of outside monitoring of managerial behavior. Furthermore, it is argued that larger institutional ownership of the firm will lead to greater following by security analysts. Therefore, it is believed that the greater the fraction of institutional ownership is the more effective the outside monitoring mechanism. ${ }^{25}$

Including the squared of the insider holdings variable, INSIDE-SQ, to account for any curvelinear insider ownership effects on leverage, the following regression model is estimated. ${ }^{26}$

$L T D="{ }_{0}+"{ }_{1} A D+"{ }_{2} S E G N U M+"{ }_{3} I N S I D E+"{ }_{4} I N S I D E \_S Q+"{ }_{5}$ OUTBLOCK + ${ }_{6} I N S T I T+$ " ${ }_{7}$ OPRISK + " ${ }_{8} P R O F$ +" ${ }_{9} N D T S+"{ }_{10} S I Z E+"{ }_{11} D I V P O R+$ " ${ }_{12} S T D L I B+\mathrm{G}_{d} I N D U M_{d}+$,

A set of two-digit SIC industry dummies $\left(I N D U M_{d}\right)$ are added in all regression models in order to control for possible industry effects on leverage.

It should be noted that after estimating model (2) separately for MNCs and domestic firms, we reestimate the model for the pooled sample using a dummy variable to allow MNCs' and

\footnotetext{
25 See, for example, O'Brien and Bhushan (1990), Moyer, Chatfield, and Sisneros (1989), Bhushan (1989).

${ }^{26}$ Several studies have shown that there is a quadratic relationship between market value and insiders' stakes. See for example, McConnell and Servaes $(1990,1995)$ where the authors based upon Stulz's arguments (1988) estimate a quadratic regression in which Tobin's $q$, their measure of firm performance, is the dependent variable.
} 
domestic firms' coefficients on each variable to differ. ${ }^{27}$ The dummy, D, is an indicator variable that takes the value of one, if the firm is an MNC, and zero if it is a domestic corporation. Specifically, the indicator variable is used to create interactive variables consisting of the product of each independent variable, $X_{i}$, and $D$ to measure the difference between MNCs and domestic firms on the coefficients of each independent variable.

The above outlined test procedure involves OLS regressions using the pooled sample of firms spanning a seven year period. The coefficients of these regressions may suffer from bias due to autocorrelation of the residuals. The reason for this is that our data set is a panel data set that has both a time series and a cross section dimension. Thus, it differs from a pooled cross sectional estimation because for an econometric analysis of panel data one cannot assume that the observations are independently distributed across time. We therefore perform panel data regression analysis that accounts for the unobservable firm effect $\left({ }_{i}\right)$, using the following fixed effects regression model:

$$
\begin{aligned}
& L T D_{i t}=\$_{0}+\$ 1 A D_{i t}+\$_{2}\left(A D^{*} D\right)_{i t}+\$_{3} S E G N U M_{t}+\$ 4 I N S I D E_{t}+\$_{5} I N S I D E_{-} S Q_{i t}+\$_{6} O U T B L O C K_{i t}+\$_{7} I N S T I T_{i t}+
\end{aligned}
$$

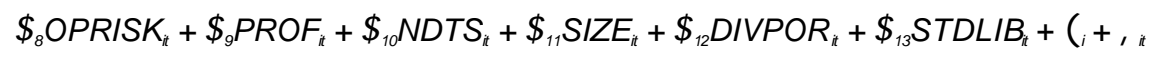

where $\mathrm{t}=1988, \ldots, 1994$.

This fixed effects regression procedure transforms the data into deviations from individual means and is appropriate because it does not rely on the assumption that the unobservable firm effect $\left(\left(_{i}\right)\right.$ is uncorrelated with the observable parameters (i.e., an assumption that underlies the random effects model). As is shown in the results section the fixed effects regression analysis was also dictated by the estimation of the Hausman $\mathrm{P}^{2}$-statistic that essentially tests whether the

\footnotetext{
${ }^{27}$ A similar estimation procedure has been used by Prowse(1990) in testing for the differences of the effects of agency costs on leverage between US and Japanese firms.
} 
coefficients of the fixed and random effects regression models are statistically different from each other. $^{28}$

\subsection{Degree of Geographic diversification and firm leverage}

To examine whether the inverse relation between alternative measures of agency costs of debt and long-term debt is exacerbated by the firm's degree of foreign involvement, we replace the multinationality dummy, $D$, in model (3) with FINV which represents the degree of the firm's foreign involvement. FINV is measured by the firm's foreign to total assets ratio. The number of foreign countries where the firm has subsidiaries is also used as an alternative measure of its foreign involvement. Hence, regression (3) obtains the following form:

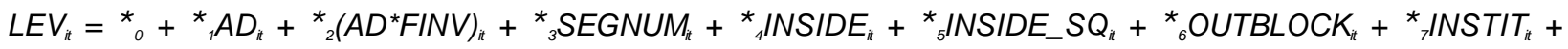

$$
\begin{aligned}
& *_{8} \mathrm{OPRISK}_{i t}+{ }_{9} \mathrm{PROF}_{i t}+{ }_{10} \mathrm{NDTS}_{i t}+{ }_{11} \mathrm{SIZE}_{i t}+{ }_{12} \mathrm{DIVPOR}_{i t}+{ }_{13} \mathrm{STDLIB}_{t}+{ }_{i}+{ }_{i t}
\end{aligned}
$$

Regression (4) will be estimated separately using long-term debt (LTD) and short-term debt (STD) as dependent variables. If the firm's foreign operations amplify the agency costs of debt on leverage, ${ }_{2}$ should be negative and significant in the $L T D$ regressions. If MNCs, however, have easier access to short-term debt markets, the interplay of agency costs of debt and the foreign involvement of the firm should be either insignificant or positive in the STD regressions.

\section{Empirical Results}

\subsection{Leverage behavior and the agency cost of debt}

In this section, we address the agency problem between shareholders and debtholders of MNCs and domestic firms by estimating regression model(2). In all regressions industry dummies at the two-digit SIC code level are used as independent variables to control for industry effects. ${ }^{29}$

\footnotetext{
${ }^{28}$ As an alternative to the panel data regressions we run OLS regressions on a year-by-year basis. The results were qualitatively similar to the ones reported here.

29 The coefficients of the the 2-digit SIC code industry dummies are not shown in the tables, but are available upon request.
} 
The regressions are performed first on the multinational and the domestic firms' samples separately. To test the hypothesis that the coefficients of the agency cost of debt variables for MNCs are significantly higher than the coefficients of domestic firms, the regressions are estimated on the pooled sample of multinational and non-multinational firms using a multinational dummy variable that permits the coefficients on each independent variable to differ between the two types of firms in the sample.

Table 2 reports results of OLS regressions with robust standard errors (White (1980) for the three measures of agency costs of debt $\left(A D_{1}, A D_{2}\right.$, and $\left.A D_{3}\right)$ on $L T D$ using cross-sections of MNCs and domestic firms pooled over the 1988-1994 period. Panel A of Table 2 shows a significant and inverse relation between long-term leverage and the different measures of agency costs of debt for both types of firms, with the exception of $A D_{1}$ in the case of the domestic sample where the relationship is negative but not significant at conventional levels. While these findings appear to be broadly consistent with those reported by Titman and Wessels (1988) and Long and Malitz (1985), the coefficients of the agency costs of debt variables for MNCs appear to be substantially larger in comparison to the domestic firms' coefficients in all three regressions, implying that agency costs of debt have greater adverse effects on the leverage of multinational than domestic firms. Moreover, it is interesting to note that the long-term debt ratio of MNCs and non-MNCs loads negatively on all three agency cost measures. However, as shown in column 4 of Panel A, the relation between longterm debt and the agency cost measures is mostly insignificant for the non-MNCs with the exception of $A D_{3}$. This indicates that among the three different agency costs of debt, free cash flowbased agency costs are the most pronounced in domestic firms. Similarly, as the magnitude of the coefficient of $A D_{3}$ suggests relative to those of $A D_{1}$ and $A D_{2}$, free cash flow-based agency costs of debt appear to be the most important for MNCs. The evidence also implies that MNCs are plagued by other agency costs that do not appear to be as severe in domestic firms. It should be 
noted, however, that the regression models with all AD measures of agency costs of debt exhibit multicolinearity among the three $A D$ variables. Therefore, subsequent regression tests are performed using models with a single AD variable at a time, as in Prowse (1990).

The SEGNUM variable is positively related with the firm's leverage, indicating that more (less) diversified firms are likely to have proportionately more (less) long-term debt in their capital structure. This is consistent with the internal capital markets view which predicts that internal capital markets tend to increase rather than decrease the external debt capacity of the industrially diversified firm. The magnitude of the coefficient of the SEGNUM variable suggests that the relation between internal capital markets and leverage is similar among MNCs and domestic firms. This evidence suggests that the external debt financing needs of the firm are not mitigated by the existence of internal capital markets (i.e., internal capital markets do not substitute for external capital markets). The other control variables have the expected signs for both samples. The coefficient of OPRISK is negative, however it is significant only for domestic firms, while the PROF variable exerts a significant negative effect on the firm's leverage for the MNCs and domestic firms. The coefficient of the OPRISK variable suggests that financial distress has less dramatic effects on the leverage of MNCs than non-MNCs. The non-debt tax shield variable is inversely related with the firm's leverage while the size variable shows a reliable and positive association with leverage for both MNCs and domestic firms.

The relationship between long-term debt $(L T D)$ and insider shareholdings (INSIDE) is shown to be positive for MNCs and negative for domestic firms. This relation, however, is mostly insignificant at conventional levels. The coefficient of the insider squared variable (INSIDE-SQ) turns negative near the $40 \%-50 \%$ of insider holdings for MNCs while it is positive and insignificant for domestic firms. In most cases the insider holdings square coefficients are insignificant and, 
therefore, the evidence does not seem to support a strong curve-linear relation between high levels of insider holdings and leverage. ${ }^{30}$

The influence of the outside blockholders (OUTBLOCK) on LTD is positive and significant in all of six regressions, consistent with the view that blockholders serve a monitoring role (see Shleifer and Vishny (1986)). The effect of institutional shareholdings on long-term leverage is negative and significant in all regressions. The negative effect of institutional shareholdings on leverage is consistent with Pound's (1988) conflict of interest and strategic alliance hypotheses which imply that institutional shareholders are inefficient monitors of managerial behavior because of the lucrative business relations that they maintain with the firms in which they have investment stakes.

\section{[Insert Table 2 Panel A About Here]}

Testing for the hypothesis that the MNC coefficients on the agency costs of debt variables are significantly larger (in absolute terms) than their domestic counterparts, the three regressions are estimated on the pooled sample that includes both the MNC and the domestic firms, using a multinationality dummy variable, $D$, to allow the coefficients on each independent variable to differ. ${ }^{31}$ These regressions, presented in Panel B of Table 2, include the same variables as before along with their interaction terms with the multinationality dummy. The coefficients of the interaction variables provide a measure of the difference in coefficients between the non-MNC and MNC firms for each independent variable.

The pattern of these results indicates that the coefficients of the three agency cost variables are significantly larger in absolute terms for MNCs in comparison to non-MNCs. The coefficients of

\footnotetext{
${ }^{30}$ Such a curvilinear relationship would be consistent with Berger, Ofek, and Yermack (1997) who showed that managerial entrenchment is inversely related to debt financing.

31 This step requires the assumption that the errors of the MNC and the non-MNC regressions are independently distributed.
} 
the interaction variable between the multinationality dummy and the three measures of agency cost of debt are $-0.0072,-0.0051$ and -0.2406 with $t$-values of $-2.85,-4.21$ and -3.18 , respectively. The significant difference between the coefficients of the agency cost variables for MNCs and non-MNCs confirms the view that the agency costs of debt are much more severe for MNCs in comparison to domestic firms. This is reconfirmed, as shown in the last column, when all three interactive measures of agency costs are included in the regression.

The coefficient of OUTBLOCK's interactive term suggests that the positive impact of outside blockholdings on leverage is stronger for non-MNCs in two out of the three models, implying that the geographic diversity of the firm renders its monitoring more difficult. In addition, the coefficients of all other independent financial variables' interactive terms are mostly insignificant, with the exception of OPRISK and DIVPOR variables, indicating that the impact of most variables on long-term leverage is similar for MNCs and domestic firms. As expected, the coefficient of the OPRISK interactive variable is positive and insignificant confirming that financial distress has less dramatic effects on the leverage of MNCs than non-MNCs.

\section{[Insert Table 2 Panel B About Here]}

Our analysis so far provides evidence in support of the view that the agency problem between shareholders and bondholders is substantially higher for firms with geographically diverse operations in comparison to firms that are geographically focused. Hence, the geographical operating diversity of the firm represents an important determinant of the firm's agency cost of debt.

\subsection{A fixed effects regression analysis}

It should be noted that the results, reported in Table 2, involve a pooling of the data over the seven year period of 1988-1994. This estimation procedure may be problematic in the sense that the correlation of the error terms across years may bias the regression coefficients. Therefore, we re-estimate model (3) using panel data regression analysis. Fixed effects regression results, 
reported in Table 3, are quite similar to those of the pooled OLS regressions listed in Table 2. ${ }^{32}$ The coefficients of the agency cost variables $\left(A D_{j}\right)$ are negative and significant, as expected, except for $A D_{1}$. Furthermore, the interaction coefficients $\left(A D_{j} \times D\right)$ for all three alternative models (using the three different $A D_{j}$ measures, one at a time) are negative and significant, indicating that the impact of the agency costs on leverage is greater (in absolute terms) for MNCs than domestic firms. The coefficients of the remaining control variables have the hypothesized signs and are mostly significant with the exception of the INSIDE, OPRISK and PROF variables. Therefore, the results from the fixed effects-panel data analysis are in conformity with the pooled regression estimations.

[Insert Table 3 About Here]

\subsection{Leverage and degree of geographic diversification}

We turn to the question of whether the degree of foreign involvement of the firm increases the negative influence of agency costs of debt on firm leverage. We use the pooled sample of MNCs and domestic firms and estimate model (4) that includes the interaction term of foreign involvement with the three measures of agency costs of debt, $\left(A D_{j} \times F I N V\right)$. The fixed effects regressions are estimated using both long-term debt, $L T D$, and short-term debt, STD, as dependent variables. Using one of the three $A D_{j}$ measures for each regression, the results are reported in Table 4.

If international operations exacerbate the agency costs of debt problem we should observe a significant negative coefficient for the $A D_{j} \times F I N V$ variable in the $L T D$ regressions and a weaker negative, or positive coefficient for $A D_{j} \times F I N V$ variable in the $S T D$ regressions. Our results are consistent with this prediction. The coefficients of the alternative interactive variables have the predicted negative and significant sign in the $L T D$ regressions and a positive (albeit insignificant in two out three regressions) sign in the STD regressions. Interestingly, these results imply that

\footnotetext{
32 The high $\mathrm{P}^{2}$-statistic of the Hausman test, reported in table 3, are significant and consistently favoring the use of the fixed effects model over a random effects model. It should be noted, however that the random effects model results are qualitatively similar to the ones presented in Table 3.
} 
increases in foreign involvement exacerbate agency costs of debt that, in turn, increase short-term leverage but worsen long-term borrowing, consistent with Barclay and Smith (1995) and Easterwood and Kadapakkam (1994) who show that firms with higher information asymmetries issue more short-term debt. These results are also in line with the evidence based on univariate tests, reported in Table 1, showing that, on the average, MNCs display lower long-term debt ratios and higher short-term debt ratios than domestic firms. The SIZE variable has a positive coefficient in all LTD and STD regressions. This indicates that larger firms are using more debt financing consistent with the notion that larger firms have an easier access to debt markets than smaller firms. ${ }^{33}$ However, in the LTD regressions the coefficient of the SIZE variable is almost double its counterpart in the STD regressions, implying that the size effect is much stronger in the case of long term debt financing. ${ }^{34}$ The other independent variables in the regressions behave similarly to those reported in Table 3.

\section{[Insert Table 4 About Here]}

\subsection{A robustness test: leverage, agency costs and the structure of foreign operations}

The previous evidence indicates that agency costs of long-term debt are greater for MNCs than domestic firms. In addition, this difference seems to arise from the geographic rather than the industrial diversification dimension of the firm. However, MNCs' lower long-term leverage could be attributed to the internal capital markets to fund projects when informational asymmetries render external financing costly. While our previous analysis controls for the existence of internal capital

\footnotetext{
${ }^{33}$ For example only the largest firms are able to issue commercial paper inexpensively, therefore they have less costly access to the short term debt market. In addition, due to the ability of larger firms to take advantage of scale economies associated with the large fixed component of issuance costs for public debt, large firms will have better access to long term debt markets. Larger firms tend to be older and more reputable firms (firms with higher credit ratings) which provides them better access to long-term debt markets.

${ }^{34}$ Previous studies have found mixed results with regards to the relationship between firm size and leverage. Titman and Wessels (1988) find that short-term debt ratios are negatively related to firm size, while Chung (1993) provides evidence that the long-(short) term debt ratio tends to decrease (increase) with firm size.
} 
markets by including corporate diversification, firm size and the interactive $\left(A D_{j} \times F I N V\right)$ measures in the regression models, we also consider the effects of the foreign operating structure of the firm on its leverage. That is, we acknowledge that the foreign involvement variable, FINV, used earlier may not be an accurate measure of the multinational operating structure of the firm.

We therefore collected information on the firm's foreign operations for the year 1990. Using the Directory of International Affiliations we identified the number of countries in which each firm in our sample had operations, and, then, we classified their operations according to the development of the country into two regions: advanced and/or developing regions, respectively. ${ }^{35}$ Therefore, model (4) is modified as follows:

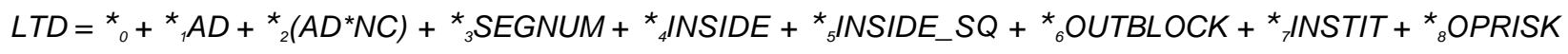

$$
\begin{aligned}
& +{ }_{9} \text { PROF }+*{ }_{10} \mathrm{NDTS}+*{ }_{11} \mathrm{SIZE}+{ }_{12} \mathrm{DIVPOR}+{ }_{13} \mathrm{REG}+\mathrm{G} 2_{d} I N D U M_{d}+
\end{aligned}
$$

where, $N C$ represents the number of foreign countries that a firm has subsidiaries. This is a more representative measure of the geographic diversity of the firm than the FINV measure (foreign asset ratio) used before. For example, consider two firms, $A$ and $B$, that both have a foreign asset ratio of $50 \%$. Firm A has foreign operations in one country while B has subsidiaries in 10 countries. Obviously the informational asymmetries would be greater in the case of B. This effect cannot be captured using the foreign asset ratio as a measure of the geographic operating dispersion of the firm. We also introduce the REG variable to capture a different aspect of the firm's geographic diversity. It measures the number of foreign regions that the firm operates. As indicated in footnote 28, we have considered eight broad geographic regions - four consisting of advanced economies, and four consisting of developing economies. REG allows us to distinguish between firms that

${ }^{35}$ We classified operations in the NAFTA area, the European Union, Western Europe, and advanced Asia (Japan, New Zealand, Australia, Hong Kong, and Singapore) as operations in "Advanced economic regions". Operations in the rest of the world were classified as operations in "Developing economic regions". We distinguished four such regions Africa, Central \& Latin America, Eastern Europe, and Developing Asia. Thus, overall we use a classification of four advanced regions and four developing regions. 
operate in the same number of foreign countries but have different degrees of geographic concentration across geographic/economic regions around the world. ${ }^{36}$

If foreign operations across countries enhance the internal capital markets advantage, the $A D \times N C$ variable should exert a positive and significant influence on the long-term leverage of the firm. That is, a positive coefficient would also imply that the interplay between agency costs of debt and geographic diversification are offset by the internal capital markets advantages. Alternatively, if agency costs of debt increase with the firm's international operations the coefficient of the interactive term $A D \times N C$ should be negative. In addition, consistent with the predictions of the internal capital markets hypothesis on firm leverage, the coefficient of REG variable should be negative, indicating that a firm with greater operating geographic diversity would use its internal capital markets for project financing to avoid costly external financing caused by the informational asymmetries associated with geographic diversification. If, however, the coefficient of $R E G$ variable is positive, that would be consistent with the alternative view of the internal capital markets hypothesis which postulates that firms with increased internal capital markets would be less prone to asymmetric information problems and hence they could sustain higher levels of debt. Alternatively, a positive relation would be consistent with the notion that firms with internationally dispersed operations make greater use of the external capital markets because of increased liquidity, lower rates and currency-risk hedging considerations.

It is expected that firms with greater operating exposure in advanced regions will have greater access to external capital markets in comparison to firms that do not. We also examine the effect of the location of the foreign operations on firm leverage, using the following model:

\footnotetext{
${ }^{36}$ For example, compare firm B and C. Both have operations in 10 foreign countries. However, B's subsidiaries are all in European Union countries, while $\mathrm{C}$ has operations in 3 European Union countries, 4 Latin American countries, one NAFTA country and two African countries. Thus the location of the foreign countries a firm operates in captures an additional dimension of the firm's degree of multinationality.
} 


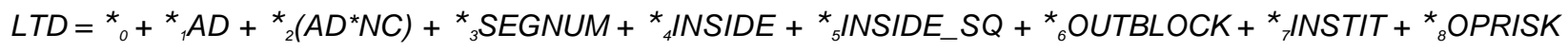

$$
+{ }_{9} P R O F+*{ }_{10} N D T S+*{ }_{11} \text { SIZE }+{ }_{12} \text { DIVPOR }+{ }_{13} \text { ADVREG }+*{ }_{14} D E V R E G+G 2 \text { INDUM }+ \text {, }
$$

where, ADVREG and DEVREG measure the number of the firm's foreign operations in advanced and developing economic regions, respectively. The internal capital markets hypothesis predicts that $*_{13}$ and $*_{14}$ will be negative. A positive $*_{13}$, would imply that firms with greater operating exposure in advanced economic regions use external financing due to greater access to developed and more liquid capital markets. Finally, if ${ }_{14}$ is found to be positive, it would suggest that external debt is likely to be motivated by currency risk considerations. However, a negative $*_{14}$ could also be attributed to the legal and institutional characteristics of the host country. This, of course, assumes that MNCs finance their operations by heavily relying on the host country's capital markets. Since this is unlikely to be the case, especially for MNCs operating in developing countries, a negative and significant $*_{14}$ is more likely to reflect the effects of internal capital markets on firm leverage.

Table 5 reports estimates of models (5) and (6). The interaction of the number of foreign countries with the three alternative measures of agency costs of debt has a significant negative coefficient in all regressions. This result is consistent with the evidence reported in Table 4 which shows that the agency costs of debt problems are exacerbated by the foreign involvement of the firm, resulting in lower leverage. Thus, these results provide additional support for the agency costs of debt hypothesis, but not for the internal capital markets hypothesis. Moreover, the coefficient of $R E G$ variable is positive, albeit insignificant in all regressions. When the $R E G$ variable is replaced by ADVREG and DEVREG variables, the coefficients remain insignificant. This indicates that geographic diversity does not have an impact on firms' long term leverage. ${ }^{37}$ Furthermore, as the

\footnotetext{
${ }^{37}$ Demirguc-Kunt and Maksimovic (1999) and Booth, Aivazian, Demirguc-Kunt and Maksimovic (2001) examine whether differences in institutional and legal environments across countries affect the leverage of firms. They find that the institutional and legal characteristics of developing countries influence the finance choices of firms in these countries.
} 
coefficients of the DEVREG variable show, the view that external financing is related to firm's currency risk considerations is not corroborated by the evidence. Finally, the insignificance of these two coefficients also suggests that legal and institutional differences across developed and developing countries have no substantive effects on MNCs' leverage. This could be mainly because MNCs are less likely to depend on the capital resources of the host country and, especially, when they operate in developing countries.

[Insert Table 5 About Here]

\section{Conclusion}

While the empirical literature has documented a negative relation between leverage and agency costs of debt for U.S. firms, in this paper we examine the extent to which this relationship is related to the international business structure of the firm. Specifically, we analyze the effects of the agency costs of debt on the leverage of 6,951 firm-year observations for multinational and nonmultinational firms over the 1988-1994 period. Furthermore, we investigate the puzzle documented in the leverage literature that multinational firms have less long-term debt but more short-term debt than domestic firms.

Univariate tests show that MNCs have, on average, higher short-term debt and lower longterm debt ratios than domestic firms. The regression models of corporate capital structure show that alternative measures of the potential conflict between shareholders and debtholders have statistically significant negative effects on firm leverage for both multinational and non-multinational corporations. The results, however, also show that the negative effect of agency costs of debt on long-term leverage is significantly greater for multinational than non-multinational firms, indicating that 
multinational firms are subject to greater agency costs of debt than firms without foreign operations. These results are consistent with the view that multinational corporations are prone to higher agency costs than domestic firms because their greater geographic diversity renders active monitoring of managerial decisions more difficult and expensive in comparison to domestic firms. Our results fail to support the view that MNCs' lower long-term debt ratios are due to the advantages that internal capital markets create. We also document that the effects of the agency costs of debt on long-term leverage are exacerbated by the firm's degree of foreign involvement. This result is also confirmed by using alternative measures of foreign involvement. 


\section{References}

Agrawal, A., and C.R. Knoeber,1996, "Firm performance and mechanisms to control agency problems between managers and shareholders", Journal Financial and Quantitative Analysis, 31 (3), 377-397, .

Ang, J., J. Chua, and J. McConnell, 1982, The administrative costs of corporate bankruptcy: A note, Journal of Finance, 37 (March), 219-226.

Barclay, Michael J., and Clifford W. Smith, 1995, The maturity structure of corporate debt, Journal of Finance, 50 (2), 609-631.

Berger, Philip G., Eli Ofek, and David L. Yermack, 1997, Managerial entrenchment and capital structure decisions, Journal of Finance, 52(4), 1411-1438.

Bhushan, Ravi, 1989, Firm characteristics and analyst following, Journal of Accounting and Economics, 11, 255-274.

Bodie, Zvi, and Robert A. Taggart, 1978, Future Investment Opportunities and the value of the Call Provision on a Bond, Journal of Finance, 33 (4), 1187-1200.

Bodnar, Gordon., and J.Weintrop,1997, The valuation of the foreign income of U.S. multinational firms: A growth opportunities perspective, Journal of Accounting and Economics,24, 69-98.

Booth, Laurence., Varouj Aivazian, Demirguc-Kunt, Asli, and Vojislav Maksimovic, 2001, Capital structures in developing countries, Journal of finance, 56,1, 87-130.

Burgman, Todd A., 1996 An empirical examination of multinational corporate capital structure, Journal of International Business Studies, 27 (3), 553-570.

Butler, Kirk C., 1999, Multinational Finance, $2^{\text {nd }}$ edition, South-Western College Publishing, Cincinnati, $\mathrm{OH}$.

Chung, Kee H., 1993, Asset characteristics and corporate debt policy: An empirical test, Journal $\phi$ Business Finance and Accounting, 20 (1), 83-97.

Comment, Robert, and Gregg A. Jarrell, 1995, Corporate focus and stock returns, Journal of Financial Economics, 37, 67-87.

Demirguc-Kunt, Asli, and Vojislav Maksimovic, 1999, Institutions, financial markets, and firm debt maturity, Journal of Financial Economics, 54, 295-336.

Denis, David J., Diane K. Denis and Atulya Sarin, 1997, Agency problems, equity ownership, and corporate diversification, Journal of Finance, 52,135-160.

Diamond, Douglas D., 1991, Debt maturity structure and liquidity risk, The Quarterly Journal of Economics, August, 105, 709-737.

Doukas, John.,1995, Overinvestment, Tobin's q and gains from foreign acquisitions, Journal of Banking \& Finance, 19, 1285-1303. 
Doukas, J., C. Kim, C. Pantzalis, 2000, Security Analysis, Agency Costs, and Company Characteristcs, Financial Analysts Journal, 56(6),54-63.

Easterwood, John C., and Palani-Rajan Kadapakkam, 1994, Agency conflicts, issue costs, and debt maturity, Quarterly Journal of Business and Economics, 33 (3), 69-80.

Fatemi, Ali M., 1988, The effect of international diversification on corporate financing policy, Journal of Business Research, 16, 17-30.

Gomi,Yugi, 1986, Guide to Japanese Taxes, Klweer law, The Netherlands.

Hermalin, Benjamin E., and Michael S. Weisbach, 1991, The effects of board composition and direct incentives on firm performance, Financial Management, 20 (4), 101-112.

Holderness, Clifford, and Dennis P. Sheehan, 1988, The role of majority shareholders in publicly held corporations: an exploratory analysis, Journal of Financial Economics, 20, 317-346.

Houston, J., C. James, and David Markus,1996, Capital market frictions and the role of internal capital markets in banking, Working Paper, University of Florida.

Jensen, Michael C., 1986, Agency costs of free cash flow, corporate finance and takeovers, American Economic Review, 76, 323-329.

John, Kose, and Eli Ofek, 1995, Asset sales and increase in focus, Journal of Financial Economics, 37, 105-126.

Kedia, Simi, and Abon Mozumdar, 1999, Is foreign currency denominated debt a hedging instrument?, Harvard University and Virginia Tech, Working Paper.

Kim, Wi Saeng, and Eric H. Sorensen, 1986, Evidence on the impact of the agency cost of debt 0 corporate debt policy, Journal of Financial and Quantitative Analysis, 21 (2), 131-144.

Kole.S.R ,1994, Managerial ownership and firm performance: incentives or rewards, Working Paper, University of Rochester.

Lang, Larry H.P., Eli Ofek and Rene M. Stulz, 1996, Leverage, investment and firm growth, Journal of Financial Economics, 40, 3-29.

Lang, Larry H.P., and Rene M. Stulz, 1994, Tobin's q corporate diversification and firm performance, Journal of Political Economy, 102, 1248-1280.

Lamont, Owen, 1997, Cash flow and investment: evidence from internal capital markets, Journal of Finance,52, 83-109.

Lee, Kwang Chul and Chuck C.Y. Kwok, 1988, Multinational corporations vs. domestic corporations: International environmental factors and determinants of capital structure, Journal of International Business Studies, 19 (2), 195-217.

Lewellen, Wilbur, 1971, A pure financial rationale for the conglomerate merger, Journal of Finance, 26, 521-537. 
Lins, K., and H. Servaes, 1999a, International evidence on the value of corporate diversification, Journal of Finance, 54, 2215-2239.

Lins, K., and H. Servaes, 1999b, Is corporate diversification beneficial in emerging markets?, Working Paper, University of North Carolina at Chapel Hill and London Business School.

Long, Michael S., and Ileen B. Malitz, 1985, Investment patterns and financial leverage, in B. Friedman (ed.), Corporate Capital Structure in the United States, Chicago: University of Chicago Press.

Matsusaka. J, and Vikram Nanda, 1997, Internal capital markets and corporate refocusing, Working Paper, University of Southern California.

McConnell, John, and Henri Servaes, 1990, Additional evidence on equity ownership and corporate value, Journal of Financial Economics, 27, 595-612.

McConnell, John, and Henri Servaes, 1995, Equity ownership and the two faces of debt, Journal $\varnothing$ Financial Economics, 39, 131-157.

Modigliani, Franco and Merton H. Miller, 1958, The cost of capital, corporation finance, and the theory of investment, American Economic Review, 48, 261-297.

Morck, Randal, Andrei Shleifer, and Robert W. Vishny, 1988, Management ownership and market valuation: an empirical analysis, Journal of Financial Economics, 20, 293-316.

Moyer, R.C., R.E. Chatfield, and P.M. Sisneros, 1989, "Security analyst monitoring activity: agency costs and information demands". Journal of Financial and Quantitative Analysis, 24 (4), 503512 .

Myers, Stewart, 1977, Determinants of Corporate Borrowing, Journal of Financial Economics, 5 (2), 147-175.

Myers, Stewart, and Nicholas S. Majluf, 1984, Corporate financing and investment decisions when firms have information that investors do not have, Journal of Financial Economics, 13(2), 321-333.

Novaes, Walter, and Luigi Zingales, 1995, Capital structure choice when managers are in control: Entrenchment versus efficiency, Unpublished working paper, University of Chicago.

O'Brien, P., and R. Bhushan, 1990, Analyst following and institutional ownership, Journal of Accounting and Economics, 28 (Supplement), 55-76.

Phelps Katherine L., William T. Moore, and L. Roenfeld ,1991, Equity valuation effects of warrantdebt financing, Journal of Financial Research, 14(2), 93-103.

Pound, J., 1988, Proxy contests and the efficiency of shareholder oversight, Journal of Financial Economics, 20, 237-265.

Prowse, Stephen D., 1990, Institutional investment patterns and corporate financial behavior in the United States and Japan, Journal of Financial Economics, 27, 43-66. 
Rajan, Raghuram, Henri Servaes, and Luigi Zingales, 2000, The cost of diversity: The diversification discount and inefficient investment, Journal of Finance 55, 35-80..

Shin Hyun-Han, and Rene and Stulz, 1998, Are internal capital markets efficient?, Quarterly Journal of Economics 113, 531-552.

Shleifer, Andrei, and Robert Vishny, 1986, Large shareholders and corporate control, Journal of Political Economy, 94, 461-488.

Shleifer, Andrei, and Robert Vishny, 1992, Liquidation values and debt capacity: A market equilibrium approach, Journal of Finance, 45, 379-396.

Scharfstein, David S, 1997, The dark side of internal capital market II, Working Paper, MIT.

Scharfstein, David S, and Jeremy C. Stein, 1997, The dark side of internal capital market: divisional rent seeking and inefficient investments, Working Paper, MIT.

Smith, C., 1977, Alternative methods of raising capital: rights versus underwritten offerings, Journal of Financial Economics, 5 (December), 273-307.

Smith, Clifford W., and Ross Watts, 1992, The investment opportunity set and corporate financing, dividend, and compensation policies, Journal of Financial Economics, 32, 263-292.

Stein, Jeremy C., 1997, Internal capital market and the competition for corporate resources, Journal of Finance, 52, 111-133.

Stulz, Rene M., 1988, Managerial control of voting rights: Financing policies and the market for corporate control, Journal of Financial Economics, 20 (1/2), 25-54.

Stulz, Rene M., 1990, Managerial Discretion and Optimal Financing Policies, Journal of Financial Economics, 26 (1), 3-28.

Thomadakis, Stavros., and Nilufer Usmen,1991, Foreign project financing in segmented capital markets: Equity versus debt, Financial Management, 20 (4), 42-53.

Titman, Sheridan, and Roberto Wessels, 1988, The determinants of capital structure choice, Journal of Finance, 43 (1), 1-19.

Warner, J., 1977, Bankruptcy costs: some evidence, Journal of Finance, 32 (May), 333-347.

White, H., 1980, A heteroscedacity-consistent covariance matrix estimator and a direct test for heteroscedasticity, Econometrica, 48, 817-838.

Williamson, Oliver E., 1975, Markets and Hierarchies: analysis and antitrust implications, Collier MacMillan Publishers Inc., New York, N.Y.

Williamson, Oliver E., 1986, Economic Organization: Firms, markets and policy control, New York University Press, New York, N.Y. 
Table 1

Summary statistics and univariate tests

PANEL A: Mean values of total debt (LEV), long-term debt (LTD), and short -term debt (STD) ratios by industrial sector for the firms in the multinational (MNCs) and the domestic (non-MNCs) samples for the 1988-1994 period.

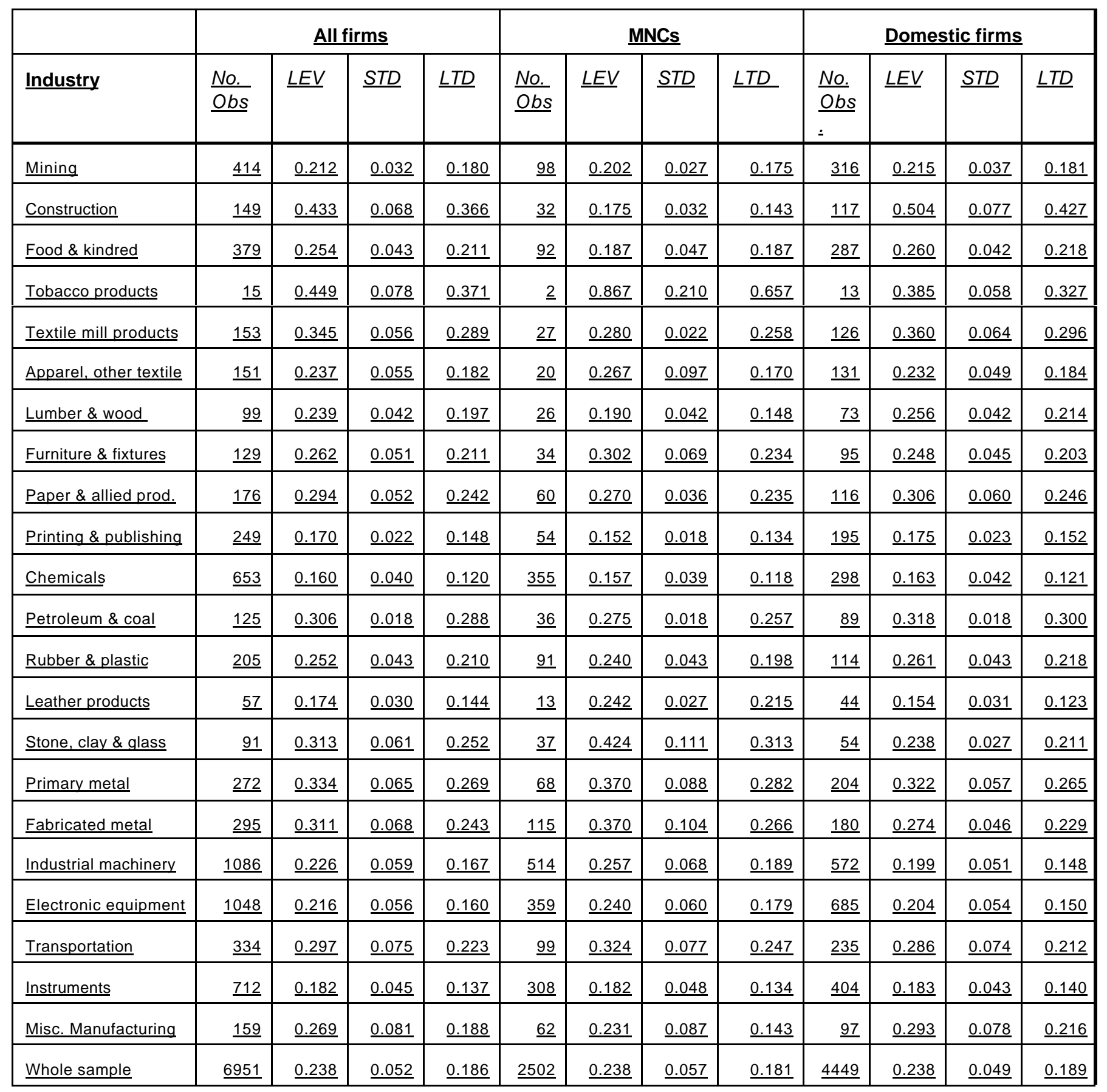

LEV: Total Debt ratio measured as $L T D+S T D$. LTD: Long Term Debt ratio measured as (Long Term Debt)/(Total Debts+Market Value of Equity). STD: Short Term Debt ratio measured as (Debt in Current Liabilities)/(Total Debts+Market Value of Equity). 



\section{$\underline{\text { Table } 1 \text { Cont'd }}$}

PANEL B:Mean and median (in brackets) values of the three differentleverage measures for the domestic sample and differentMNC samples constructed based on the MNCs' degree of foreign involvement. Foreign involvement (FINV) is measured by the foreign asset ratio (FAR=foreign assets/total assets) and the foreign sales ratio (FSALER=foreign sales/total sales). The three leverage measures are:Long term debtratio ( $L T D$ ), measured as (Long Term Debt)/(Total Debt+MarketValue of Equity); Short term debtratio (STD) measured as (Debt in Current Liabilities)/(Total Debt+Market Value of Equity); Total debt ratio (LEV measured as the sum of $L T D$ and STD. The convertible debt ratio (CONV), is measured as (Long Term Debt Convertible to Common or Preferred Stocks)/(Total Long Term Debt).

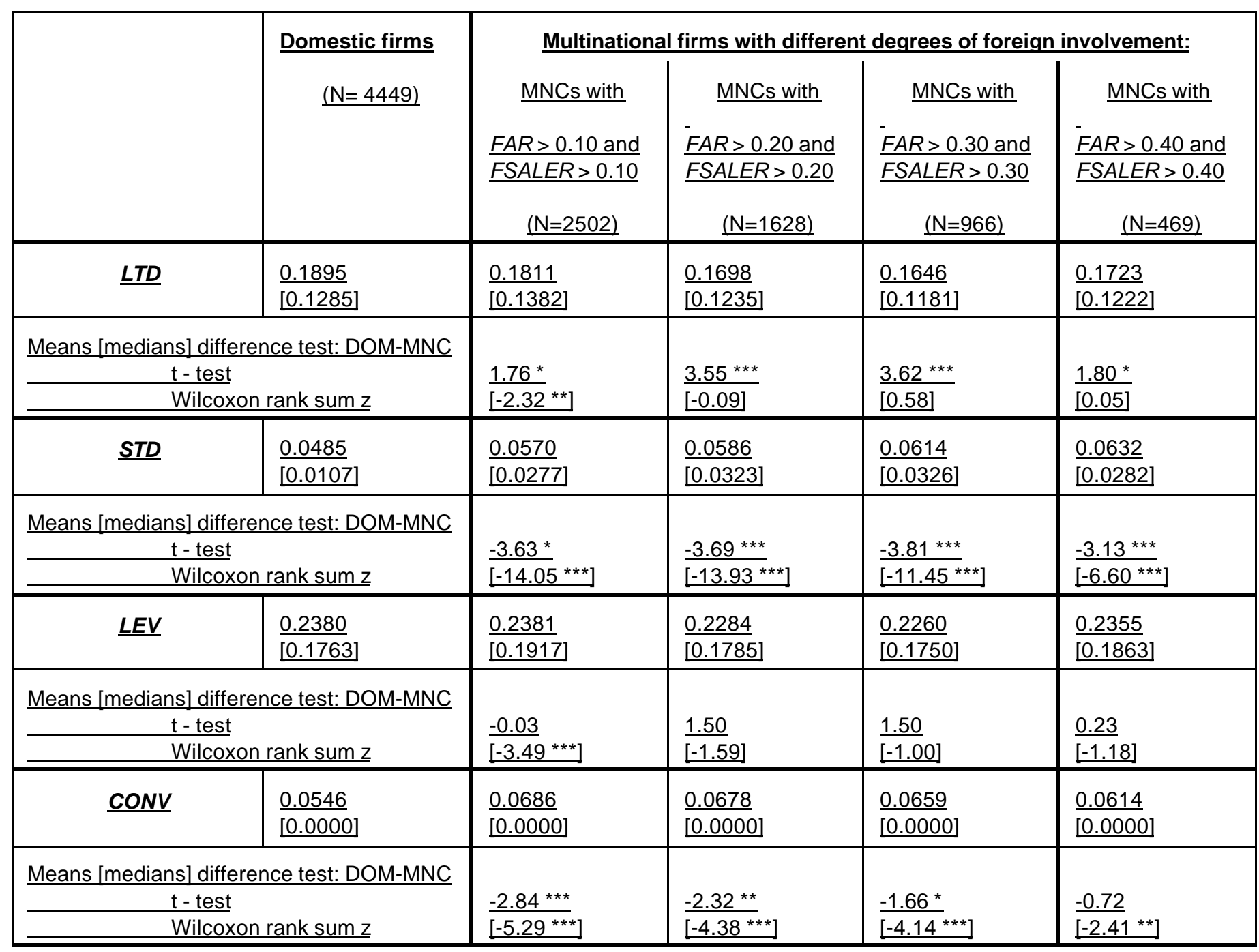




\section{Table 1 Cont'd}

PANEL C: Means and standard deviations of the variables included in the regression models for the firms in the multinational (MNCs) and the domestic (non-MNCs) samples for the 1988-1994 period.

\begin{tabular}{|c|c|c|c|c|c|}
\hline \multirow{2}{*}{$\underline{\text { Variable }}$} & \multicolumn{2}{|c|}{ MNCs $(\mathrm{N}=2502)$} & \multicolumn{2}{|c|}{ Domestic firms ( $N=4449)$} & \multirow{2}{*}{$\begin{array}{c}\text { L(Mean) test } \\
\underline{\text { t-statistic }}\end{array}$} \\
\hline & Mean & Std. Deviation & Mean & $\underline{\text { Std. Deviation }}$ & \\
\hline$\underline{A D 1^{a}}$ & 2.1969 & 3.3828 & 2.6628 & 22.3441 & $\underline{-0.98}$ \\
\hline$\underline{A D 2}$ & $\underline{3.1959}$ & $\underline{5.1848}$ & $\underline{4.3560}$ & $\underline{11.0757}$ & $\underline{-4.69^{* * *}}$ \\
\hline$\underline{A D 3}$ & $\underline{0.0729}$ & $\underline{0.0818}$ & $\underline{0.0645}$ & $\underline{0.0999}$ & $\underline{3.60}^{* * *}$ \\
\hline$\underline{\text { SEGNUM }}$ & $\underline{1.9556}$ & $\underline{1.2903}$ & $\underline{1.6723}$ & $\underline{1.1073}$ & $\underline{9.64}^{* * *}$ \\
\hline OPRISK & $\underline{0.0324}$ & $\underline{0.0478}$ & $\underline{0.0517}$ & $\underline{0.0877}$ & $\underline{-10.24^{* * *}}$ \\
\hline$\underline{P R O F}$ & $\underline{0.0406}$ & $\underline{0.1006}$ & $\underline{0.0279}$ & $\underline{0.1222}$ & $\underline{4.40}^{* * *}$ \\
\hline$\underline{S I Z E}$ & $\underline{1722.35}$ & $\underline{5150.35}$ & $\underline{614.46}$ & 3743.91 & $10.30^{* \star *}$ \\
\hline NDTS & $\underline{0.0575}$ & $\underline{0.0455}$ & $\underline{0.0540}$ & $\underline{0.0488}$ & $\underline{2.94^{* * *}}$ \\
\hline DIVPOR & $\underline{44.2062}$ & $\underline{1151.82}$ & $\underline{41.8900}$ & $\underline{848.24}$ & $\underline{0.10}$ \\
\hline INSIDE & $\underline{16.09}$ & $\underline{20.72}$ & $\underline{22.06}$ & $\underline{21.41}$ & $-11.27^{* * *}$ \\
\hline OUTBLOCK & $\underline{18.94}$ & $\underline{21.71}$ & $\underline{18.12}$ & $\underline{21.09}$ & $\underline{1.55}$ \\
\hline INSTIT & $\underline{43.34}$ & $\underline{21.56}$ & $\underline{30.00}$ & $\underline{20.88}$ & $\underline{25.27}$ \\
\hline$\underline{C A / T A^{a}}$ & $\underline{0.5452}$ & $\underline{0.1674}$ & $\underline{0.5697}$ & $\underline{0.2001}$ & $\underline{-5.14^{* * *}}$ \\
\hline
\end{tabular}

a The number of observations for $A D_{1}(C A / T A)$ are 2266 (2467) for the MNC sample and 3855 (4295) for the Domestic firms' sample, due to missing observations.

$\stackrel{* * * * *}{*}$ indicate significance at the $10 \%, 5 \%$ and $1 \%$ levels, respectively.

$\underline{A D}=$ Market-to-book ratio defined as market value of equity divided by the book value of equity.

$A D_{2}=$ (Total Assets)/(Gross Fixed Assets).

$A D_{3}=$ (Operating Income before Depreciation - Taxes -Interest expense- Dividends)/(Total Assets).

$S E G N U M=$ Number of business segments.

OPRISK = Standard deviation of (Earnings before Interest Expense and Taxes/Sales) for the past 5 years.

$P R O F=$ Average (Net Income/Sales) for the past three years.

SIZE = Total Assets.

$\underline{N D T S}=$ [Operating Income - Interest Expense - (Taxes paid/Tax rate)]/Sales, where the Tax rate is assumed to be $43 \%=38 \%$ (Federal) $+5 \%($ State) .

$\underline{D I V P O R}=$ Total dollar amount of dividends (other than stock dividends) declared on the common stock, divided by Income Before Extraordinary ltems, adjusted for common stock equivalents, which represents income before extraordinaryitems and discontinued operations less preferred dividend requirements (adjusted for common stock equivalents). This figure is then multiplied by 100. $I N S I D E=$ Insider shareholdings as a percent of total common shares outstanding.

OUTBLOCK = Outside blockholders stake as a percent of total common shares outstanding.

$I N S T I T=$ Institutional shareholdings as a percent of total common shares outstanding.

$\underline{C A / T A}=$ Current assets as a percentage of total assets. 
Table 2

Regressions with robust standard errors of Long-Term Debt on Agency Cost of Debt

PANEL A: Results of regression with robuststandard errors (White (1980)) for long-term debt (LTD) ratios for multinational (MNCs) and domestic (non-MNCs) manufacturing firms on three measures of agencycost of debt for the period 1988-1994. Reported are the regression coefficients and t-values (in parentheses). Coefficients on two-digit SIC code industry dummies are not reported. The model is $L T D_{j}=a+b_{i} X_{j}+e$, where $X_{j}$ represents independent variable $i$, for each firm j, including the two-digit SIC code industry dummies. The dependentvariable is $L T D=$ (Long Term Debt)/(Total Debt + Market Value of Equity). The independentvariables are: $A D_{1}=$ Market-to-book ratio. $A D_{2}=$ Total Assets/Gross Fixed Assets. $A D_{3}=$ (Operating Income before Depreciation - Interest expense -Taxes - Dividends)/Total Assets. SEGNUM=Number of business segments. INSIDE $=\%$ of shares held by insiders. INSIDE-SQ $=$ INSIDE-squared. INSTIT $=\%$ of shares held by institutions. OUTBLOCK $=\%$ of shares held by outside blockholders. OPRISK = Std dev. of (EBIT/Sales) for the past 5 years. $P R O F=$ Average (Net Income/Sales) for the past three years. SIZE =Total Assets. NDTS = [Operating Income - Interest Expense - (Taxes paid/Tax rate)]/Sales. DIVPOR = total dollar amount of dividends (other than stock dividends) declared on the common stock, divided by Income Before Extraordinary Items, adjusted for common stock equivalents. $\underline{S T D L I B}=$ Annual standard deviation of the 3-month LIBOR rate using weekly observations. " " ", and "' denote significance at the $10 \%$, the $5 \%$, and the $1 \%$ levels, respectively.

\begin{tabular}{|c|c|c|c|c|c|c|c|c|}
\hline \multirow[b]{2}{*}{$\begin{array}{l}\text { Independ. } \\
\text { Variables }\end{array}$} & \multicolumn{2}{|c|}{ (1) } & \multicolumn{2}{|c|}{ (2) } & \multicolumn{2}{|c|}{ (3) } & \multicolumn{2}{|c|}{ (4) } \\
\hline & MNCs & $\frac{\text { Domestic }}{\text { firms }}$ & MNCs & $\frac{\text { Domestic }}{\text { firms }}$ & MNCs & $\frac{\text { Domestic }}{\text { firms }}$ & MNCs & $\frac{\text { Domestic }}{\underline{\text { firms }}}$ \\
\hline Intercept & $\begin{array}{r}0.22877^{-\prime} \\
\quad 12.19) \\
\end{array}$ & $\begin{array}{r}0.1639 \cdots \\
\underline{(10.42)} \\
\end{array}$ & $\begin{array}{r}0.2326 \\
\underline{(13.20)} \\
\end{array}$ & $\begin{array}{l}0.1716{ }^{-*} \\
\underline{(11.78)} \\
\end{array}$ & $\begin{array}{r}0.2190 \\
(12.26) \\
\end{array}$ & $\begin{array}{r}0.1682 \cdots \\
\underline{(11.61)} \\
\end{array}$ & $\begin{array}{c}0.2341 \\
\underline{(13.22)} \\
\end{array}$ & $\begin{array}{l}0.1617 \\
\underline{(10.25)} \\
\end{array}$ \\
\hline$\underline{A D_{1}}$ & $\begin{array}{c}-0.0073^{*} \\
-(-2.89) \\
\end{array}$ & $\begin{array}{r}-0.0001 \\
\underline{(-0.82)} \\
\end{array}$ & & & & & $\frac{-0.0054}{\underline{(-3.07)}}$ & $\begin{array}{r}-0.0001 \\
\underline{(-0.77)} \\
\end{array}$ \\
\hline$\underline{A D_{2}}$ & & & $\frac{-0.0052}{(-4.31)}$ & $\frac{-0.0001{ }^{*}}{\underline{(-2.07)}}$ & & & $\frac{-0.0051}{(-5.78)}$ & $\frac{-0.0005}{(-1.54)}$ \\
\hline$\underline{A D_{3}}$ & & & & & $\frac{-0.50633^{*-}}{(-8.04)}$ & $\begin{array}{r}\frac{-0.26566^{\cdots}}{(-6.33)} \\
\end{array}$ & $\begin{array}{r}-0.4731 \\
\end{array}$ & $\frac{-0.3112}{(-6.54)}$ \\
\hline SEGNUM & $\frac{0.0276}{(8.87)}$ & $\frac{0.0269}{\underline{(6.79)}}$ & $\frac{0.0262 \cdots "}{(8.89)}$ & $\frac{0.02366^{-\prime}}{(8.42)}$ & $\frac{0.0272}{(9.12)}$ & $\frac{0.0228}{(8.22)}$ & $\frac{0.0251}{(8.42)}$ & $\frac{0.0228{ }^{*}}{(7.81)}$ \\
\hline INSIDE & $\frac{0.0006}{(1.15)}$ & $\frac{-0.0002}{\underline{(-0.37)}}$ & $\begin{array}{c}\underline{0.0007^{*}} \\
\underline{(1.66)} \\
\end{array}$ & $\frac{-0.0001}{(-0.33)}$ & $\begin{array}{r}0.0007 \\
\underline{(1.42)} \\
\end{array}$ & $\frac{-0.0001}{(-0.18)}$ & $\frac{0.0011^{*}}{\underline{(2.38)}}$ & $\frac{0.0000}{\underline{(0.01)}}$ \\
\hline INSIDE-SQ & $\frac{-6.52 \times 10^{-6}}{(-1.04)}$ & $\frac{6.54 \times 10^{-6}}{(1.18)}$ & $\frac{-0.000001}{\underline{-(1.31)}}$ & $\begin{array}{r}\frac{4.47 \times 10^{-6}}{(0.92)} \\
\end{array}$ & $\frac{-5.55 \times 10^{-6}}{(-0.96)}$ & $\frac{3.53 \times 10^{-6}}{(0.74)}$ & $\frac{-11.5 \times 10^{-6}}{(-1.88)}$ & $\begin{array}{r}4.96 \times 10^{-6} \\
\underline{(0.91)} \\
\end{array}$ \\
\hline OUTBLOCK & $\frac{0.00042}{(2.87)}$ & $\frac{0.00098}{\underline{(6.05)}}$ & $\frac{0.00043^{-}}{(3.14)}$ & $\frac{0.00104}{(6.97)}$ & $\frac{0.00047^{-\prime}}{(3.39)}$ & $\frac{0.00097}{(6.56)}$ & $\frac{0.00037^{\cdots *}}{\underline{(2.65)}}$ & $\frac{0.00095}{(5.92)}$ \\
\hline INSTIT & $\frac{-0.0010}{\underline{(-5.39)}}$ & $\frac{-0.0011^{\prime \prime}}{\underline{(-7.29)}}$ & $\frac{-0.0011}{\underline{(-6.14)}}$ & $\frac{-0.0012 \cdots}{(-8.47)}$ & $\frac{-0.0010}{(-5.45)}$ & $\frac{-0.0011}{\underline{(-7.28)}}$ & $\frac{-0.0007}{(-4.12)}$ & $\frac{-0.0009}{(-5.94)}$ \\
\hline OPRISK & $\frac{-0.0115}{(-0.09)}$ & $\frac{-0.3674}{(-7.52)}$ & $\frac{-0.0882}{(-0.90)}$ & $\frac{-0.3295}{(-7.91)}$ & $\frac{-0.1640}{\underline{(-1.52)}}$ & $\frac{-0.3487^{-*}}{\underline{(-8.32)}}$ & $\frac{-0.0547}{\underline{(-0.54)}}$ & $\frac{-0.3582}{(-7.07)}$ \\
\hline$\underline{P R O F}$ & $\frac{-0.2477}{(-3.86)}$ & $\frac{-0.3169}{(-7.82)}$ & $\frac{-0.1861}{(-3.37)}$ & $\frac{-0.2864}{(-8.74)}$ & $\frac{-0.2212}{(-3.90)}$ & $\frac{-0.2671{ }^{\cdots}}{(-8.26)}$ & $\frac{-0.1919^{*}}{(-4.39)}$ & $\frac{-0.2821}{(-7.08)}$ \\
\hline$\underline{N D T S}$ & $\frac{-0.3492}{(-4.40)}$ & $\frac{-0.3185}{(-5.46)}$ & $\frac{-0.4639}{(-5.63)}$ & $\frac{-0.2956}{(-5.63)}$ & $\frac{-0.0777}{\underline{(-0.81)}}$ & $\begin{array}{r}-0.0275 \\
\underline{(-0.43)} \\
\end{array}$ & $\frac{0.0548}{\underline{(0.53)}}$ & $\frac{-0.0151}{(-0.21)}$ \\
\hline SIZE & $\frac{2.38 \times 10^{-6}}{(2.92)}$ & $\frac{1.73 \times 10^{-6}}{(4.32)}$ & $\frac{1.60 \times 10^{-6}}{(1.66)}$ & $\frac{2.1 \times 10^{-6}}{(3.51)}$ & $\frac{1.49 \times 10^{-6}}{(1.62)}$ & $\frac{1.95 \times 10^{-6}}{(3.53)}$ & $\frac{1.88 \times 10^{-6}}{(2.60)}$ & $\frac{1.62 \times 10^{-6}}{(4.29)}$ \\
\hline
\end{tabular}




\begin{tabular}{|c|c|c|c|c|c|c|c|c|}
\hline DIVPOR & $\frac{8.87 \times 10^{-6}}{(3.73)}$ & $\frac{2.11 \times 10^{-6}}{\underline{(0.66)}}$ & $\frac{8.89 \times 10^{-6}}{(3.48)}$ & $\frac{1.65 \times 10^{-6}}{(0.53)}$ & $\frac{2.44 \times 10^{-6^{*}}}{(1.87)}$ & $\frac{0.56 \times 10^{-6}}{\underline{(0.18)}}$ & $\frac{2.95 \times 10^{-6} "}{(2.16)}$ & $\frac{0.74 \times 10^{-6}}{\underline{(0.22)}}$ \\
\hline$\underline{S T D L I B}$ & $\frac{-0.0207 "}{(-2.00)}$ & $\frac{0.0020}{\underline{(0.21)}}$ & $\frac{-0.0171}{\underline{(-1.74)}}$ & $\frac{0.0011}{\underline{(0.13)}}$ & $\frac{-0.0124}{\underline{(-1.26)}}$ & $\frac{0.0039}{\underline{(0.45)}}$ & $\frac{-0.0159}{\underline{(-1.58)}}$ & $\begin{array}{r}0.0034 \\
\underline{(0.37)}\end{array}$ \\
\hline$\frac{\text { Industry }}{\text { dummies }}$ & $\underline{\text { YES }}$ & $\underline{\text { YES }}$ & $\underline{\text { YES }}$ & YES & $\underline{\text { YES }}$ & YES & $\underline{\text { YES }}$ & $\underline{\text { YES }}$ \\
\hline$\frac{\frac{\text { Adjusted }^{2}}{\mathrm{~F} \text {-value }}}{\underline{\underline{N}}}$ & $\frac{0.2244}{\frac{16.34}{2266}}$ & $\frac{\frac{0.1653}{20.27}}{\frac{3855}{3855}}$ & $\begin{array}{r}\frac{0.2232}{17.48} \\
\underline{2502}\end{array}$ & $\begin{array}{r}\frac{0.1715}{25.46} \\
\underline{4449} \\
\end{array}$ & $\frac{\frac{0.2250}{22.73}}{\underline{2502}}$ & $\frac{\frac{0.1833}{27.34}}{\underline{4449}}$ & $\begin{array}{r}\frac{0.2774}{22.95} \\
\underline{2266}\end{array}$ & $\begin{array}{r}\frac{0.1825}{22.50} \\
\underline{3855} \\
\end{array}$ \\
\hline
\end{tabular}

$\underline{\text { Table } 2 \text { Cont'd }}$

PANEL B:Results of regression with robust standard errors (White (1980)) for long-term debt (LTD) ratios for multinational (MNCs) and domestic (non-MNCs) manufacturing firms on three measures of agency cost of debt, and on the common equity ownership structure variables for the period 1988-1994 using a multinationality dummy $(D)$ to allow MNC and non-MNC coefficients on each variable to differ. Reported are the direct estimates of the difference between the non-MNC and MNC coefficients on each independent variable. $\mathrm{t}-\mathrm{values}$ are reported in parentheses. Coefficients on the non-MNC independent variables, the two-digit SIC

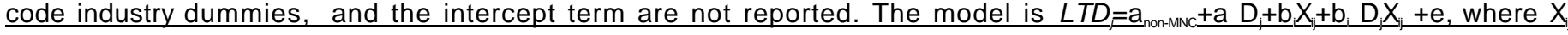
represents independentvariable $\mathrm{l}$, for each firm $\mathrm{j}$, including the two-digit SIC code industry dummies. The dependent variable is $L T D$ $\equiv$ (Long Term Debt)/(Total Debt + Market Value of Equity). The independent variables are: $A D_{1}=$ Market-to-book ratio. $A D_{2}=$ Total Assets/Gross Fixed Assets. $A D_{3}=$ (Operating Income before Depreciation - Interest expense -Taxes - Dividends)/Total Assets. SEGNUM = Number of business segments. INSIDE $=\%$ of shares held by insiders. INSIDE-SQ = INSIDE-squared. INSTIT $\%$ of shares held by institutions. OUTBLOCK $=\%$ of shares held by outside blockholders. OPRISK $=$ Std dev. of (EBIT/Sales) for the past 5 years. $P R O F=$ Average (NetIncome/Sales) for the past three years. SIZE =Total Assets. NDTS=[Operating Income - Interest Expense - (Taxes paid/Tax rate)]/Sales. DIVPOR = total dollar amount of dividends (other than stock dividends) declared on the common stock, divided by Income Before Extraordinary Items, adjusted for common stock equivalents. STDLIB= Annual standard deviation of the 3-month LIBOR rate using weekly observations. " " "' denote significance at the $10 \%, 5 \%$, and $1 \%$ levels. respectively.

\begin{tabular}{|c|c|c|c|c|}
\hline $\begin{array}{l}\text { Independent } \\
\text { Variables }\end{array}$ & (1) & (2) & (3) & (4) \\
\hline$\underline{A D_{1}} \times \underline{D}$ & $\frac{-0.0072}{(-2.85)}$ & & & $\frac{-0.0053}{(-3.00)}$ \\
\hline$\underline{A D}_{2} \times D$ & & $\frac{-0.0051}{(-4.21)}$ & & $\frac{-0.0046}{(-4.90)}$ \\
\hline$\underline{A D}_{3} \times D$ & & & $\frac{-0.2406}{(-3.18)}$ & $\frac{-0.1619}{(-1.87)}$ \\
\hline$\underline{S E G N U M \times D}$ & $\begin{array}{l}\frac{-0.0033}{(-0.63)} \\
\end{array}$ & $\underline{0.0026}$ & $\underline{0.0044}$ & $\begin{array}{r}-0.0033 \\
(-0.63) \\
\end{array}$ \\
\hline$\underline{I N S I D E \times D}$ & $\frac{0.0008}{(1.11)}$ & $\frac{0.0008}{(1.36)}$ & $\begin{array}{l}0.0007 \\
(1.20) \\
\end{array}$ & $\underline{0.0011}$ \\
\hline$\underline{I N S I D E-S Q \times D}$ & $\frac{-13.1 \times 10^{-6}}{\underline{(-1.55)}}$ & $\frac{-0.000012}{(-1.60)}$ & $\frac{-0.000009}{(-1.21)}$ & $\frac{-16.4 \times 10^{-6}}{\underline{(-2.01)}}$ \\
\hline OUTBLOCK $\times D$ & $\frac{-0.00057}{\underline{(-2.61)}}$ & $\frac{-0.00061}{\underline{(-2.98)}}$ & $\frac{-0.00050 "}{\underline{(-2.48)}}$ & $\frac{-0.00058}{\underline{(-2.72)}}$ \\
\hline$\underline{I N S T I T \times D}$ & $\frac{0.0001}{(0.33)}$ & $\frac{0.0001}{\underline{(0.57)}}$ & $\frac{0.0001}{(0.31)}$ & $\frac{0.0002}{\underline{(0.67)}}$ \\
\hline$\underline{O P R I S K \times D}$ & $\frac{0.3559}{\underline{(2.69)}}$ & $\frac{0.2413}{(1.98)}$ & $\frac{0.1847}{(1.60)}$ & $\frac{0.3035}{\underline{(2.31)}}$ \\
\hline$\underline{P R O F \times D}$ & $\frac{0.0692}{(0.91)}$ & $\frac{0.1004}{(1.56)}$ & $\frac{0.0459}{(0.70)}$ & $\frac{0.0902}{\underline{(1.52)}}$ \\
\hline
\end{tabular}




\begin{tabular}{|c|c|c|c|c|}
\hline$\underline{N D T S \times D}$ & $\frac{-0.0307}{(-0.31)}$ & $\frac{-0.1683}{\underline{(-1.72)}}$ & $\begin{array}{l}0.1052 \\
\underline{(0.91)} \\
\end{array}$ & $\underline{0.0699}$ \\
\hline$\underline{S I Z E \times D}$ & $\frac{0.65 \times 10^{-6}}{\underline{(0.72)}}$ & $\frac{-4.73 \times 10^{-6}}{(-0.42)}$ & $\frac{-4.56 \times 10^{-6}}{(-0.42)}$ & $\frac{0.26 \times 10^{-6}}{\underline{(0.31)}}$ \\
\hline$\underline{D I V P O R \times D}$ & $\frac{-6.76 \times 10^{-6}}{(-1.70)}$ & $\frac{7.24 \times 10^{-6}}{\underline{(1.80)}}$ & $\frac{1.88 \times 10^{-6}}{\underline{(0.54)}}$ & $\frac{2.20 \times 10^{-6}}{\underline{(0.61)}}$ \\
\hline$\underline{S T D L I B \times D}$ & $\begin{array}{r}-0.0227 \\
(-1.63) \\
\end{array}$ & $\begin{array}{l}\frac{-0.0182}{(-1.38)} \\
\end{array}$ & $\frac{-0.0163}{(-1.24)}$ & $\begin{array}{l}\frac{-0.0194}{(-1.42)} \\
\end{array}$ \\
\hline $\begin{array}{l}\frac{\text { Adjusted } R^{2}}{\underline{\text { F-value }}} \\
\underline{N}\end{array}$ & $\frac{\frac{0.1836}{18.09}}{\underline{6121}}$ & $\frac{\frac{0.1871}{\underline{21.21}}}{\underline{6951}}$ & $\frac{\underline{0.1960}}{\underline{24.77}}$ & $\frac{\frac{0.2119}{22.47}}{\underline{612}}$ \\
\hline
\end{tabular}


Table 3

Fixed effects regressions of Long-Term Debt on Agency Cost of Debt and its interaction with the MNC dummy

This table contains fixed effects regressions results using the pooled sample of all firms. Reported are the coefficients and the corresponding $\mathrm{t}$-values (in parentheses) for the following variables: $A D_{1}=$ Market-to-book ratio. $A D_{2}=$ Total Assets/Gross Fixed Assets. $A D_{3}=$ (Operating Income before Depreciation - Interestexpense-Taxes - Dividends)/Total Assets. The agencycost variables $\left(A D_{j}\right)$ are also interacted with a multinationality dummyvariable (D), which takes the value of one if the firm is an MNC and the value of zero, otherwise. SEGNUM = Number of business segments. INSIDE $=\%$ of shares held by insiders. INSIDE-SQ = INSIDEsquared. INSTIT $=\%$ of shares held by institutions. OUTBLOCK $=\%$ of shares held by outside blockholders. OPRISK $=$ Std dev. of (EBIT/Sales) for the past 5 years. PROF = Average (Net Income/Sales) for the past three years. SIZE $=$ Total Assets. NDTS = [Operating Income - Interest Expense - (Taxes paid/Tax rate)]/Sales. DIVPOR = total dollar amount of dividends (other than stock dividends) declared on the common stock, divided by Income Before Extraordinary ltems, adjusted for common stock equivalents. $\underline{S T D L I B}=$ Annual standard deviation of the 3-month LIBOR rate using weekly observations. The dependent variables is measured as $L T D=$ (Long Term Debt)/(Total Debt + Market Value of Equity) and STD=(Debt in Current Liabilities)/(Total Debt+Market Value of Equity). Coefficients on the two-digit SIC code industry dummies included in the regression model term are not reported. ",", denote significance at the $10 \%, 5 \%$, and $1 \%$ levels, respectively.

\begin{tabular}{|c|c|c|c|}
\hline$\frac{\text { Independent }}{\text { Variables }}$ & $\begin{array}{l}\text { Agency cost }\left(A D_{i}\right) \\
\text { measured by } A D_{1}\end{array}$ & $\begin{array}{l}\text { Agency cost }\left(A D_{j}\right) \\
\text { measured by } A D_{2}\end{array}$ & $\begin{array}{l}\text { Agency cost }\left(A D_{j}\right) \\
\text { measured by } A D_{3}\end{array}$ \\
\hline$\underline{\text { Intercept }}$ & $\frac{0.2078}{(4.82)}$ & $\frac{0.2169}{(5.27)}$ & $\frac{0.2085}{(5.11)}$ \\
\hline$\underline{A D}_{i}$ & $\frac{-0.0000}{(-0.12)}$ & $\frac{-0.0002}{\underline{(-3.40)}}$ & $\frac{-0.2130}{\underline{(-9.52)}}$ \\
\hline$\underline{A D_{i}} \times \underline{D}$ & $\frac{-0.0023}{\underline{(-3.49)}}$ & $\frac{-0.0022}{\underline{(-3.42)}}$ & $\frac{-0.0796 "}{\underline{(-2.21)}}$ \\
\hline SEGNUM & $\frac{0.0165}{(4.00)}$ & $\frac{0.0167}{(4.22)}$ & $\frac{0.0182}{(4.65)}$ \\
\hline INSIDE & $\frac{0.0001}{(0.36)}$ & $\frac{0.0003}{\underline{(0.99)}}$ & $\underline{0.0027}$ \\
\hline INSIDE-SQ & $\frac{4.15 \times 10^{-6}}{\underline{(1.20)}}$ & $\frac{1.83 \times 10^{-6}}{\underline{(0.56)}}$ & $\frac{1.78 \times 10^{-6}}{\underline{(0.55)}}$ \\
\hline OUTBLOCK & $\frac{0.00052}{\underline{(4.30)}}$ & $\frac{0.00056}{\underline{(4.90)}}$ & $\frac{0.00051}{(4.45)}$ \\
\hline INSTIT & $\frac{-0.0023 \cdots}{(-13.73)}$ & $\frac{-0.0022}{(-13.94)}$ & $\frac{-0.0020}{(-12.93)}$ \\
\hline OPRISK & $\underline{0.0136}$ & $\begin{array}{l}-0.0031 \\
(-0.09) \\
\end{array}$ & $\frac{-0.0013}{(-0.04)}$ \\
\hline$\underline{P R O F}$ & $\underline{0.0006}$ & $\frac{-0.0152}{(-0.64)}$ & $\frac{-0.0312}{(-1.33)}$ \\
\hline$\underline{N D T S}$ & $\frac{-0.2211}{(-5.80)}$ & $\frac{-0.2179 \cdots}{\underline{(-6.11)}}$ & $\frac{-0.0099}{(-0.25)}$ \\
\hline$\underline{S I Z E}$ & $\frac{2.92 \times 10^{-6} \cdots}{(4.42)}$ & $\frac{2.47 \times 10^{-6}}{(3.83)}$ & $\frac{2.41 \times 10^{-6} \cdots}{(3.77)}$ \\
\hline$\underline{D I V P O R}$ & $\frac{3.29 \times 10^{-6}}{\underline{(2.45)}}$ & $\frac{3.25 \times 10^{-6}}{\underline{(2.38)}}$ & $\frac{1.05 \times 10^{-6}}{\underline{(0.77)}}$ \\
\hline$\underline{S T D L I B}$ & $\frac{-0.0101 "}{(-2.39)}$ & $\frac{-0.0093}{(-2.31)}$ & $\frac{-0.0073}{(-1.81)}$ \\
\hline Industry dummies & $\underline{\text { Yes }}$ & $\underline{\text { Yes }}$ & $\underline{\text { Yes }}$ \\
\hline 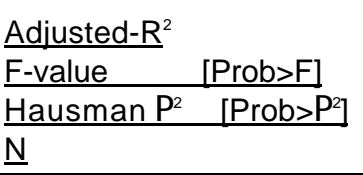 & $\frac{\frac{0.0693}{13.23[0.000]}}{\frac{166.31[0.000]}{\underline{6121}}}$ & $\frac{\frac{0.0667}{14.21[0.000]}}{\frac{121.88[0.000]}{\underline{6951}}}$ & $\frac{\frac{0.0871}{18.97[0.000]}}{\frac{126.37[0.000]}{\underline{6951}}}$ \\
\hline
\end{tabular}




\section{Table 4}

\section{Fixed effects regressions of Long-Term and Short-Term Debt on Agency Cost of Debt measures and their interaction with the degree of foreign involvement}

This table contains fixed effects regressions results using the pooled sample of all firms. Reported are the coefficients and the corresponding t-values (in parentheses) for the following variables: $A D_{1}=$ Market-to-book ratio. $A D_{2}=$ Total Assets $/$ Gross Fixed Assets. $A D_{3}=$ (Operating Income before Depreciation - Interestexpense-Taxes - Dividends)/Total Assets. The agency cost variables $\left(A D_{j}\right)$ are also interacted with the degree of foreign involvement (FINV) which is measured by the ratio of foreign assets over total assets. SEGNUM= Number of business segments. INSIDE =\% of shares held byinsiders. INSIDE-SQ = INSIDE-squared. INSTIT $\equiv \%$ of shares held by institutions. OUTBLOCK $=\%$ of shares held by outside blockholders. OPRISK $=$ Std dev. of (EBIT/Sales) for the past 5 years. $P R O F=$ Average (Net Income/Sales) for the past three years. SIZE = Total Assets. NDTS = [Operating Income Interest Expense - (Taxes paid/Tax rate)]/Sales. DIVPOR = total dollar amount of dividends (other than stock dividends) declared on the common stock, divided by Income Before Extraordinary Items - Adjusted For Common Stock Equivalents. STDLIB=Annual standard deviation of the 3-month LIBOR rate using weekly observations. The dependent variables is measured as $L T D=$ (Long Term Debt)/(Total Debt + Market Value of Equity) and $S T D=$ (Debt in Current Liabilities)/(Total Debt+Market Value of Equity). Coefficients on the two-digit SIC code industry dummies included in the regression model term are not reported. ",", "' denote significance at the $10 \%, 5 \%$, and $1 \%$ levels, respectively.

\begin{tabular}{|c|c|c|c|c|c|c|}
\hline \multirow{3}{*}{$\begin{array}{l}\text { Independent } \\
\text { Variable }\end{array}$} & \multicolumn{2}{|c|}{$\begin{array}{l}\text { Agency cost }\left(A D_{i}\right) \\
\text { measured by } A D_{1}\end{array}$} & \multicolumn{2}{|c|}{$\begin{array}{l}\text { Agency cost }\left(A D_{i}\right) \\
\text { measured by } A D_{2}\end{array}$} & \multicolumn{2}{|c|}{$\begin{array}{l}\text { Agency cost }\left(A D_{i}\right) \\
\text { measured by } A D_{3}\end{array}$} \\
\hline & \multicolumn{2}{|c|}{ Dependent variable } & \multicolumn{2}{|c|}{ Dependent variable } & \multicolumn{2}{|c|}{ Dependent variable } \\
\hline & $\underline{L T D}$ & $\underline{S T D}$ & $\underline{L T D}$ & $\underline{S T D}$ & $\underline{L T D}$ & $\underline{S T D}$ \\
\hline Intercept & $\frac{0.2059}{(4.78)}$ & $\frac{0.1038}{\underline{3.29)}}$ & $\frac{0.2170}{(5.27)}$ & $\frac{0.0915}{(3.23)}$ & $\frac{0.2089}{\underline{(5.12)}}$ & $\frac{0.0885}{(3.14)}$ \\
\hline$\underline{A D_{i}}$ & $\frac{-0.0000}{\underline{(-0.11)}}$ & $\frac{-0.0001^{*}}{\underline{(-1.67)}}$ & $\frac{-0.0002}{(-3.38)}$ & $\frac{-0.00003}{\underline{(-1.03)}}$ & $\frac{-0.2087}{\underline{(-9.69)}}$ & $\frac{-0.1031^{\prime \prime}}{\underline{(-6.94)}}$ \\
\hline$\underline{A D \times F I N V}$ & $\frac{-0.0068}{\underline{(-4.19)}}$ & $\underline{\underline{0.0022}}$ & $\frac{-0.0101}{(-5.04)}$ & $\underline{0.0019}$ & $\frac{-0.2856}{(-3.27)}$ & $\frac{0.0227}{(0.38)}$ \\
\hline SEGNUM & $\frac{0.0170}{\underline{(4.14)}}$ & $\frac{0.0048}{(1.60)}$ & $\frac{0.0168}{\underline{(4.24)}}$ & $\underline{0.0042}$ & $\underline{\underline{0.0180}} \frac{}{\underline{(4.59)}}$ & $\frac{0.0049}{(1.80)}$ \\
\hline INSIDE & $\frac{0.00013}{(0.43)}$ & $\frac{-0.0003}{(-0.19)}$ & $\frac{0.00028}{(0.98)}$ & $\frac{-0.00024}{(-1.19)}$ & $\frac{0.00027}{(0.94)}$ & $\frac{-0.00025}{(-1.30)}$ \\
\hline INSIDE-SQ & $\frac{3.94 \times 10^{-6}}{(1.14)}$ & $\frac{2.72 \times 10^{-6}}{(1.07)}$ & $\frac{1.92 \times 10^{-6}}{(0.59)}$ & $\frac{2.19 \times 10^{-6}}{\underline{(0.97)}}$ & $\frac{1.78 \times 10^{-6}}{\underline{(0.55)}}$ & $\frac{2.31 \times 10^{-6}}{\underline{(1.04)}}$ \\
\hline OUTBLOCK & $\frac{0.0005}{(4.35)}$ & $\frac{-0.0000}{\frac{(-0.45)}{2}}$ & $\frac{0.0006}{(4.94)}$ & $\frac{-0.0000}{\frac{(-0.44)}{2}}$ & $\frac{0.0005}{(4.48)}$ & $\frac{-0.0001}{\frac{(-0.73)}{2}}$ \\
\hline INSTIT & $\frac{-0.0023}{\underline{(-13.59)}}$ & $\frac{-0.0012}{(-9.96)}$ & $\frac{-0.0022}{(-13.82)}$ & $\frac{-0.0011^{\cdots-}}{(-9.98)}$ & $\frac{-0.0020}{(-12.94)}$ & $\frac{-0.0010}{(-9.08)}$ \\
\hline OPRISK & $\frac{0.0141}{(0.36)}$ & $\frac{0.0835}{(2.92)}$ & $\frac{-0.0019}{\frac{(-0.05)}{1}}$ & $\frac{0.07133^{\cdots}}{(2.91)}$ & $\frac{-0.0044}{\frac{(-0.12)}{12}}$ & $\frac{0.0705}{(2.89)}$ \\
\hline PROF & $\underline{\underline{0.0011}}$ & $\frac{0.1086}{\underline{(5.60)}}$ & $\frac{-0.0174}{\underline{(-0.73)}}$ & $\frac{0.0853}{\underline{(5.24)}}$ & $\frac{-0.0353}{(-1.50)}$ & $\underline{\underline{0.0786}}^{-{ }^{\prime \prime}}$ \\
\hline$\underline{N D T S}$ & $\frac{-0.2195}{(-5.76)}$ & $\frac{-0.1661}{(-5.95)}$ & $\frac{-0.2147}{(-6.03)}$ & $\frac{-0.1437}{(-5.88)}^{(-1}$ & $\frac{-0.0058}{(-0.15)}$ & $\frac{-0.0560 "}{(-2.06)}$ \\
\hline SIZE & $\frac{2.76 \times 10^{-6}}{(4.22)}$ & $\frac{1.40 \times 10^{-6}}{(2.93)}$ & $\frac{2.44 \times 10^{-6}}{(3.78)}$ & $\frac{1.46 \times 10^{-6}}{(3.31)}$ & $\frac{2.37 \times 10^{-6}}{(3.72)}$ & $\frac{1.43 \times 10^{-6}}{(3.24)}$ \\
\hline$\underline{D I V P O R}$ & $\frac{3.29 \times 10^{-6}}{(2.44)}$ & $\frac{-0.38 \times 10^{-6}}{(-0.39)}$ & $\frac{3.24 \times 10^{-6}}{(2.38)}$ & $\frac{-0.40 \times 10^{-6}}{(-0.43)}$ & $\frac{0.96 \times 10^{-6}}{(0.71)}$ & $\frac{-1.18 \times 10^{-6}}{(-1.26)}$ \\
\hline$\underline{S T D L I B}$ & $\frac{-0.0100^{*}}{(-2.38)}$ & $\frac{-0.0073^{*}}{(-2.35)}$ & $\frac{-0.0092}{(-2.28)}$ & $\frac{-0.0065 " *}{(-2.34)}$ & $\frac{-0.0072}{(-1.80)}$ & $\frac{-0.0057^{*}}{(-2.06)}$ \\
\hline
\end{tabular}




\begin{tabular}{|c|c|c|c|c|c|c|}
\hline Ind.dummies & Yes & Yes & Yes & $\underline{\text { Yes }}$ & Yes & Yes \\
\hline Adjusted $R^{2}$ & $\underline{0.0703}$ & $\underline{0.0433}$ & $\underline{0.0691}$ & $\underline{0.0375}$ & $\underline{0.0881}$ & $\underline{0.0466}$ \\
\hline F-value $\quad[$ Prob $>F]$ & $13.44 \quad[0.000]$ & $8.04 \quad[0.000]$ & $14.75[0.000]$ & $7.75 \quad[0.000]$ & $19.21 \quad[0.000]$ & $\underline{9.72}[0.000]$ \\
\hline Hausman $\mathrm{P}_{2}^{2}\left[\mathrm{Prob}>\mathrm{P}_{2}\right.$ & $154.83[0.000]$ & $\begin{array}{ll}89.56 & {[0.000]} \\
\end{array}$ & $119.36[0.000]$ & $99.86[0.000]$ & $123.97[0.000]$ & $91.40[0.000]$ \\
\hline$\underline{\mathrm{N}}$ & 6121 & 6121 & 6951 & 6951 & 6951 & $\underline{6951}$ \\
\hline
\end{tabular}

Table 5

Regressions with robust standard errors of Long-Term Debt on Agency Cost of Debt measures and on different measures of the multinational network structure

Results of regression with robust standard errors (White (1980)) for the year 1990 using the pooled sample of firms. The long-term debt $(L T D)$ ratios are regressed on three measures of agency cost of debt, and on differentmultinational network variables. This table reports regression coefficients and the corresponding t-values (in parentheses) for the following variables: $A D_{1}=$ Market-to-book ratio. $A D_{2}=$ Total Assets/Gross Fixed Assets. $A D_{3}=$ (Operating Income before Depreciation - Interest expense -Taxes - Dividends)/ Total Assets. The agency cost variables $\left(A D_{j}\right)$ are also interacted with the number of foreign countries a firm operates in $(N C)$. SEGNUM= Number of business segments. INSIDE $=\%$ of shares held by insiders. INSIDE-SQ = INSIDE-squared. INSTIT $=\%$ of shares held by institutions. OUTBLOCK $=\%$ of shares held by outside blockholders. OPRISK $=$ Std dev. of (EBIT/Sales) for the past 5 years. $P R O F=$ Average (Net Income/Sales) for the past three years. SIZE = Total Assets. NDTS = [Operating Income - Interest Expense - (Taxes paid/Tax rate)]/Sales. DIVPOR = total dollar amount of dividends (other than stock dividends) declared on the common stock, divided by Income Before Extraordinaryltems, adjusted for common stock equivalents. $R E G=$ Number of foreign regions that the firm operates in. $A D V R E G=$ Number of advanced economic regions that the firm operates in. $D E V R E G=$ Number of developing economic regions that the firm operates in. The dependent variable is measured as $L T D=$ (Long Term Debt)/(Total Debt + Market Value of Equity). Coefficients on the two-digit SIC code industry dummies included in the regression model term are not reported. " ,", "' denote significance at the $10 \%, 5 \%$, and $1 \%$ levels, respectively.

\begin{tabular}{|c|c|c|c|c|c|c|}
\hline \multirow{2}{*}{$\begin{array}{l}\text { Independent } \\
\text { Variable } \\
\text { Intercept }\end{array}$} & \multicolumn{2}{|c|}{$\begin{array}{c}\text { Agency cost of debt }\left(A D_{j}\right) \\
\text { is measured by } A \underline{D}_{1}\end{array}$} & \multicolumn{2}{|c|}{$\begin{array}{c}\text { Agency cost of debt }\left(A D_{j}\right) \\
\text { is measured by } A D_{2}\end{array}$} & \multicolumn{2}{|c|}{$\begin{array}{c}\text { Agency cost of debt }\left(A D_{j}\right) \\
\text { is measured by } A D_{3}\end{array}$} \\
\hline & $\underline{0.2052}{ }^{(5.52)}$ & $\underline{0.2049}$ & $\underline{\underline{0.2220}}{ }^{(6.24)}$ & $\frac{0.2215}{(6.22)}$ & $\underline{0.2367}{ }^{-1}$ & $\underline{\underline{0.2356}}{ }^{-*}$ \\
\hline$\underline{A D}_{j}$ & $\frac{-0.0004}{(-0.96)}$ & $\frac{-0.0004}{(-0.95)}$ & $\frac{-0.0032}{(-2.06)}$ & $\frac{-0.0032}{(-2.06)}$ & $\frac{-0.1877^{*}}{(-1.98)}$ & $\frac{-0.1889}{(-1.99)}$ \\
\hline$\underline{A D_{j}} \times N C$ & $\frac{-0.0006}{(-2.64)}$ & $\frac{-0.0005}{(-2.41)}$ & $\frac{-0.0010}{(-3.70)}$ & $\frac{-0.0010}{(-3.57)}$ & $\frac{-0.0303}{(-2.80)}$ & $\frac{-0.0290}{(-2.69)}$ \\
\hline$\underline{\text { SEGNUM }}$ & $\frac{0.0255}{(4.58)}$ & $\frac{0.0255}{(4.57)}$ & $\frac{0.0219}{(4.01)}$ & $\frac{0.0219}{(4.01)}$ & $\frac{0.0219}{(4.10)}$ & $\frac{0.0219}{(4.10)}$ \\
\hline INSIDE & $\underline{\underline{0.00090}}$ & $\underline{\underline{0.00090}}$ & $\underline{0.00080}$ & $\frac{0.00080}{(0.85)}$ & $\underline{0.00026}$ & $\underline{0.00028}$ \\
\hline INSIDE-SQ & $\frac{-0.53 \times 10^{-6}}{(-0.05)}$ & $\frac{-0.60 \times 10^{-6}}{(-0.05)}$ & $\frac{0.68 \times 10^{-6}}{(0.06)}$ & $\frac{0.59 \times 10^{-6}}{(0.05)}$ & $\frac{2.95 \times 10^{-6}}{(0.30)}$ & $\frac{2.65 \times 10^{-6}}{(0.27)}$ \\
\hline OUTBLOCK & $\underline{\underline{0.0014}}$ & $\underline{\underline{0.0014}}{ }^{\prime 3.58)}$ & $\underline{\underline{0.0011}}$ & $\underline{\underline{0.0011}}$ & $\frac{0.0012}{(3.34)}$ & $\underline{\underline{0.0012}}$ \\
\hline INSTIT & $\frac{-0.0012}{(-3.15)}$ & $\frac{-0.0012}{(-3.15)}$ & $\frac{-0.0013}{(-3.40)}$ & $\frac{-0.0013}{(-3.40)}$ & $\frac{-0.0013^{*}}{(-3.62)}$ & $\frac{-0.0014}{(-3.67)}$ \\
\hline OPRISK & $\frac{-0.5842}{(-3.91)}$ & $\frac{-0.5829}{(-3.90)}$ & $\frac{-0.4578}{(-3.01)}$ & $\frac{-0.4563}{(-3.00)}$ & $\frac{-0.6103}{(-4.66)}$ & $\frac{-0.6067}{(-4.63)}$ \\
\hline$\underline{P R O F}$ & $\frac{-0.4495}{(-4.05)}$ & $\frac{-0.4491}{(-4.05)}$ & $\frac{-0.3825}{(-4.14)}$ & $\frac{-0.3821}{(-4.13)}$ & $\frac{-0.3115}{(-3.85)}$ & $\frac{-0.3102}{(-3.84)}$ \\
\hline$\underline{N D T S}$ & $\frac{-0.2042}{(-1.27)}$ & $\frac{-0.2044}{(-1.28)}$ & $\frac{-0.26088^{\circ}}{\underline{-1.66)}}$ & $\frac{-0.2603}{(-1.66)}$ & $\begin{array}{l}\frac{-0.1458}{(-0.91)} \\
\end{array}$ & $\frac{-0.1448}{-(-0.91)}$ \\
\hline SIZE & $\frac{0.94 \times 10^{-6} \cdots}{(3.73)}$ & $\frac{0.97 \times 10^{-6}}{\underline{(3.69)}}$ & $\frac{1.00 \times 10^{-6} \cdots}{(3.70)}$ & $\frac{1.02 \times 10^{-6}}{(3.76)}$ & $\frac{0.98 \times 10^{-6} \cdots}{(3.76)}$ & $\frac{0.96 \times 10^{-6} \cdots}{(3.94)}$ \\
\hline$\underline{D I V P O R}$ & $\frac{0.000002}{(0.06)}$ & $\frac{0.000001}{\underline{(0.05)}}$ & $\frac{-0.000004}{(-0.13)}$ & $\frac{-0.000004}{\frac{(-0.14)}{-10}}$ & $\frac{-0.00005}{\frac{(-1.01)}{1.0}}$ & $\frac{-0.00005}{\frac{(-1.01)}{1}}$ \\
\hline
\end{tabular}




\begin{tabular}{|c|c|c|c|c|c|c|}
\hline$\underline{R E G}$ & $\frac{0.0028}{(0.63)}$ & & $\frac{0.0066}{\underline{(1.42)}}$ & & $\frac{0.0044}{(0.94)}$ & \\
\hline$\underline{A D V R E G}$ & & $\frac{0.0038}{(0.63)}$ & & $\frac{0.0077}{\underline{(1.27)}}$ & & $\frac{0.0071}{\underline{(1.13)}}$ \\
\hline$\underline{D E V R E G}$ & & $\frac{0.0005}{\underline{(0.05)}}$ & & $\frac{0.0041}{\underline{(0.41)}}$ & & $\frac{-0.0017}{(-0.17)}$ \\
\hline Ind. dummies & $\underline{\text { Yes }}$ & $\underline{\text { Yes }}$ & $\underline{\text { Yes }}$ & $\underline{\text { Yes }}$ & $\underline{\text { Yes }}$ & $\underline{\text { Yes }}$ \\
\hline $\begin{array}{l}\frac{\mathrm{N}}{\text { Adj. } \mathrm{R}^{2}} \\
\text { F-value }\end{array}$ & $\begin{array}{l}\frac{866}{0.1657} \\
\underline{6.86}\end{array}$ & $\begin{array}{l}\frac{866}{\underline{0.1657}} \\
\underline{6.69}\end{array}$ & $\frac{\frac{972}{0.1716}}{\frac{7.45}{\underline{4}}}$ & $\frac{\frac{972}{0.1717}}{\underline{7.23}}$ & $\begin{array}{l}\frac{972}{\underline{0.1755}} \\
\underline{8.80}\end{array}$ & $\begin{array}{l}\frac{972}{\underline{0.1755}} \\
\underline{8.80}\end{array}$ \\
\hline
\end{tabular}

